\title{
The Degree of Readiness to Total Distance Learning in the Face of COVID-19 - Teachers' View (Case of Azerbaijan, Georgia, Iraq, Nigeria, UK and Ukraine)
}

\author{
Natela Doghonadze* \\ Aydin Aliyev** \\ Huda Halawachy*** \\ Ludmila Knodel**** \\ Adebayo Samuel Adedoyin ${ }^{* * * * *}$
}

\begin{abstract}
By distance learning we understand an educational situation in which a teacher and his/her students are not placed in one physical environment. Distance learning was first applied in the $19^{\text {th }}$ century and has undergone a long way of technological improvement. It has become indispensable in the time of global pandemic. It is characterized by both advantages and challenges, and, correspondingly, in normal situations is used by adults for additional education or at any level /age in combination with traditional face-to-face education. The goal of this paper is to assess how ready we turned out to be to involuntary, caused by extreme situation of coronavirus, switching over to distance learning. The article presents results obtained from six countries - Azerbaijan, Georgia, Iraq, Nigeria, UK, and Ukraine - as well as some views of educators from several other countries. Although the samples were not representative by number of the research populations, they tried to take into consideration the strata involved (school/university teachers, younger than 30,31-50, older than 50), in order to be trustworthy. The conclusion made is that the trend is that we (at least, in many countries, or many of us) are still rather far from ready to carry out so often declared and advertised distance learning with optimal efficiency and much work is needed to be able to switch to high-quality distance education.
\end{abstract}

Key words: distance learning, e-learning, technical readiness, psychological readiness, pedagogical readiness, COVID-19

\section{Introduction}

By distance learning we understand an educational situation in which a teacher and his/her students are not placed in one physical environment. The concept of distance learning is more than 170 years old: shorthand courses were offered in Britain and educational materials sent to students by mail. The technological era for distance learning began with the spread of radio and television and eventually computers. In 1960 the University of Illinois created Intranet for its students who were able to use educational materials via it (Peterson's, n.d.).

In the Soviet Union there existed a sort of distance learning, called extramural higher education, which united distance learning during the semesters and short face-to-face classes during the examination sessions. The diploma obtained in this way

\footnotetext{
* Prof. Dr. International Black Sea University, Georgia

** Dr. Azerbaijan State University of Economics, Azrbaijan

${ }^{* * *}$ Dr. University of Mosul, Iraq

${ }^{* * * *}$ Prof. Dr. National University of Technologies and Design, Ukraine

****** Independent Researcher

Coresponding Email: nateladoghonadze@ibsu.edu.ge
} 
was legally as recognized, as face-to-face studies. However, the system was destroyed after the collapse of the USSR (Prokofiev, Chilikin \& Tulpanov, 1961)

Online schools and open universities where all education is done online exist nowadays in many countries of the world (see, for instance, https://compare.onlinecolleges.com/onlinecolleges?quad=https://o1.qnsr.com/cgi/r?;n=203;c=1657161;s=27409; $x=7936 ; f=201$ 808161158400; $u=j ; z=$ TIMESTAMP; $\& \mathrm{ad}=343936170843 \& \mathrm{fb}=\mathrm{all} \% 20 \% 2 \mathrm{Bonline} \% 20 \% 2 \mathrm{Bschools} \& \mathrm{mt}=\mathrm{b} \&$ adposition=\&dev=c\&PP CIntLoc $=2840 \& P P C P h y s L o c=1007469 \& W T . s r c h=1 \&$ exp $=y \& r p v k=27783110 \& \mathrm{rvk}=29118310 \& \mathrm{gclid}=$ EAlalQobChMlgofLpLXO6A IVDuR3Ch2Tyg-iEAAYASAAEgLzGPD_BwE;. https://www.masterstudies.com/universities/Russia/Russia-Online/. Not only quality of their teaching differs from school to school and from university to university, but so do the recognition of credits gained there and their diplomas. Institutionally accredited online institutions and accredited distance programs offered by traditional universities usually have curricula and educational materials corresponding to national standards, so their quality is more or less reliable (Colleges and Degrees, 2020).

The fact that distance / online / mobile / e-learning has a lot of advantages can already be viewed as a proved fact which does not need any extra proofs. It is also very popular among learners and young teachers. The topic has been discussed in dozens of researches (e.g., Dumford \& Miller, 2018; Gossenheimer, Bem, Carneiro, \& de Castro, 2017; .Naidu, 2019; Sadeghi, 2019; Santana de Oliveira, \& Torres Penedo, \& Pereira, 2018). Among the advantages named in these publications are that it:

- $\quad$ supports autonomy and self-learning;

- $\quad$ is flexible in time and place;

- $\quad$ is cheaper that traditional education;

- $\quad$ is time-saving (no commuting)

- enables to combine work and study;

- $\quad$ normally provides educational materials;

- $\quad$ engages students more (they seldom "miss" classes);

- $\quad$ is available for students with special needs.

However, there are certain challenges involved in distance learning, too:

- $\quad$ various distractions (due to lack of teacher control over the situation);

- lack of technical skills by teachers and, less so, by students;

- $\quad$ lack of social interaction between students;

- quality of both teaching and learning, which may be worse than in traditional education;

- $\quad$ need in taking measures to discipline and organize students;

- $\quad$ less personalized contact with teachers;

- $\quad$ less individual approach to students (if any);

- $\quad$ less culture-sensitive approach;

- $\quad$ few or no cooperatively done tasks; 
- lower quality of interactions (they are superficial);

- $\quad$ no socializing on campus;

- $\quad$ difficulty in getting teacher's scaffolding;

- $\quad$ limitations with specialties (like medicine, also those that require experimentation);

- mostly limited to English and a few other languages, such as German and Russian.

Some advantages / drawbacks, viewed by various authors, are contradictory. Concerning the costs of distance education, for instance, some researchers doubt its cost-effectiveness due to high drop-out rates (Lenn, 2004). It is cheaper, true, but not always cost-effective. The quality of teaching both in traditional education and online learning depends on teachers' knowledge of contemporary teaching methods and ability of their application, so it might not be a challenge comparatively to traditional teaching.

As distance learning, together with really essential advantages, entails some challenges as well, diplomas of open universities, even if legally recognized in the country, are not very welcome by employers (Bozkurt, 2019). Due to it, till very recently, distance education has been mostly applied as additional (often post-diploma) education or a combination of traditional and e-learning has been in use. In connection with COVID 19, however, suddenly, the whole world had to switch over for an indefinite period to distance learning, because the alternative to it was stopping any education, which, of course, is unacceptable. This situation has revealed how realistic it is to switch over to distance learning and what problems exist in this connection. The goal of this paper is to try to assess how ready we are to involuntary, caused by necessity switching over to distance learning. There are, of course, many other respects of the evolved problem, such as defining all challenges and - what is especially important - ways of dealing with them, but this article concentrates only on diagnosing the readiness for overwhelming distance learning.

According to Learning Portal (2020), 185 countries in Asia, Europe, the Middle East, North America and South America had to close schools and universities due to COVID-19 pandemic. This, of course, had a great impact on what has been happening in the widest-ever application of distance learning in these countries.

\section{What has been happening worldwide in distance learning this spring?}

\subsection{Georgia}

In connection with COVID-19 first vacations were announced in schools a week before the scheduled time, to carry out disinfection (Ministry of Education, Science, Culture and Sport of Georgia, 2020, March 10). Georgian government, due to the declared state of emergency in the country, issued a resolution on measures to prevent the spread of the new Coronavirus (COVID-19) in Georgia. As the classes could not start after vacations, all education in the country went online (Ministry of Education, Science, Culture and Sport of Georgia, 2020 March 23).

Although, according to the Law of Georgia on General Education (2005), schools have to be technologically equipped and Information Technology should be taught to students, the amount of equipment and the Internet and its quality is not always relevant, and many teachers do not have adequate technical skills, especially in small rural schools. So, it is possible to say that the speed of digitalization of education in the country is insufficient.

The 15 Georgian schools applying innovative education methodologies thanks to the ongoing partnership programme between UNICEF Georgia, the Government of Estonia, and the Government of Georgia called New School Model, were best 
prepared to switch over to distance learning (Ministry of Education, Science, Culture and Sport of Georgia, 2020 March 1), but even in those schools the process of relevant curriculum and educational materials development was only in the process and teacher training in that direction had not been completed.

Although everybody realizes that such a sudden introduction of distance learning was caused by protecting students' and teachers' health, on the one hand, and the necessity of continuing the education in the situation of indefinite duration, according to Etaloni.ge (2020, March 26), school teachers claim that they are shocked, as they are not technically well enough equipped, there are few educational resources in Georgian, so teachers have to work day and night to cope with the problem. Compared to countries where they have had online schools with their curricula, educational and testing materials, which in the arising situation could be used by other schools as well, Georgia did not have such materials. International schools and Higher education programs doing their education in English turned out to be in a much better situation, as many companies and universities offered them in these hard days educational software and materials (in English, of course).

Some schools and universities initiated distance learning even earlier than it was ordered by the Ministry (Agenda.ge, 2020, March 11). However, it turned out that not all universities and especially public schools were relevantly prepared for distance learning. Lack of ready-made online materials (videos, drills, etc.) in the Georgian language puts the whole burden on teachers' shoulders, however, not for all subjects it is possible (in physics and chemistry students need to conduct or at least to watch laboratory work).

The Law of Georgia on Higher Education (2004) provides a definition of e-learning as "study process or a part thereof, based on modern information and communication technologies and organised by a higher education institution for persons staying on the territory of Georgia for obtaining qualification, which process does not provide for simultaneous presence of students and a teacher at a specific place" (article 2, $\mathrm{t}^{1}$ ). According to article 3 of the Law, higher education institutions have to develop technologies, however, even the accreditation standards do not require a really high level of students' and teachers' technical skills and, what is especially important, teachers' methodological skills for effective application of educational technologies. This or that way, the majority of teachers managed to urgently buy computer-compatible video cameras, to upload distance learning platforms such as Zoom, Coursera, Hangouts Meet, Teams, etc. generously offered for free in these hard days, register there, invite students to online meetings. However, they do not know how to make this kind of teaching not simply watching a "talking head", but an interesting and effective educational process. And nobody is offering them these kinds of webinars.

Many university students, unable to go to the library, discovered that their university library does not possess all educational materials in digital format, so their teachers had to "digitalize" (just take photos) of the needed materials for them. While having only digital copies of books (plus a printout) at the university library is permitted by the accreditation standards, having electronic copies for all educational materials has never been a demand.

For those students who do not have internet access, especially in rural areas, the government from April 1 introduced television lessons by, as they claim, best teachers, but there already are some complaints about the irrelevance of some lessons to the topics studied and the knowledge level of students. So, luckily, they remembered that distance learning can be done not only via internet. Anyway, this was a very necessary (cannot say very timely, as this could have been organized earlier) measure for rural schools and for those children who went to villages for vacations and got stuck there. The effort has been rather successful and appreciated by those who could not benefit from the internet (and not only them), so from April 14 they started to broadcast also classes for ethnic minorities in respective languages, however, it should be noted that it should have been done earlier. 
Some Georgian publishing houses announced that schoolchildren could benefit from free-of-charge online textbooks and additional resources (Sulakauri, 2020, March 13). EU is contributing €20million assistance to Georgia, including $€ 11.3$ million in small grants to civil society organisations (CSOs) across the Eastern Partnership region, which can provide local schools with distance learning (Delegation of the European Union to Georgia, 2020).

Teachers' associations according to subjects are doing much to help teachers, they share video-recorded materials and ideas. National Center for Teacher Professional Development (http://old.tpdc.ge/index.php?action=page\&p_id=50\&lang=eng) on April 10 started webinars for school teachers in order to provide some methodological / pedagogical recommendations, however, it should have been done earlier.

With all measures taken, some Georgian officials do recognize the great challenges the country's education system came across in connection with switching to distance learning (Gorgodze, 2020). They recognize (mostly school) teachers' irrelevant technical skills. Those digital educational materials developed in the Georgian language that exist are not systematized and often not of high quality and variety. Parents happened to not be very much linked to school (no information was available on e-mail or social networking addresses). On the other hand, teachers state that legislation dealing with online learning has been discussed for years, but not much progress in this direction has been made. The new (temporary) lifestyle happened to be very stressful to students, parents and teachers. The hardware and software available to students put them into harshly different social groups. It took the Ministry too long time to develop the instructions for schools.

By now, on the whole, the critical situation with distance learning has been more or less tackled with, however, midterm exams are approaching at universities (and, probably, final exams will have to be held in quarantine conditions, too) and conducting them online is another problem educational administrators and teachers will have to deal with.

From informal correspondence with other teachers it is possible to add that, although many teachers view the unprepared introduction of online education as stressful and difficult, they admit that they had to learn how they should apply it and they achieved certain success eventually. As in Georgia it is difficult to get an academic position at universities, many young teachers, including PhDs, work as invited lecturers at 2-3 universities to make enough money for living. They mentioned the difficulty of having to use different platforms for teaching, which are more or less similar, however, one needs to spend time to learn to use each and not to be confused. And, of course, many teachers complain about the lack (almost non-existence) of online educational materials in the Georgian language. School teachers complain about problems with eyesight, as they have not only to deliver classes online, but also to download and correct students' homework and prepare lessons, as well as communicate with students and parents beyond lessons online, so they have to spend more than 40 weekly hours in front of computer, which, of course, is not normal. Had there been software that would correct test-like tasks, their work would have been much easier.

The webinar Universities and COVID-19 Pandemic (Youtube, 2020) revealed that some universities went online earlier (March 12) than the Ministry recommended them to do so (March 16). Out of the 56 accredited universities in Georgia three are newly accredited ones and have no students yet, all others eventually managed to go online, which can be positively assessed, however, the information on the percentage of the students who are 'covered' by distance learning is only being collected by universities now. At smaller private universities online trainings for personnel were timely held, which enabled them to go online relatively painlessly. At the same webinar it was mentioned 'to record or not to record' and then 'to upload to social media or not to upload' was discussed from copyright viewpoint, so university administrations left uploading to lecturers. Another problem that arose - and could not be solved - is exchange programs, which had to be delayed for an indefinite period. It is unclear yet how final exams and especially MA and PhD defenses will be held. As distance learning is carried out in combination with 'stay at home' quarantine situation, both teachers and students need psychological support to remove the stress. 
According to Raimers and Schleicher (2020), a Microsoft Office 365 user profile (up to 600,000 students and up to 55,000 teachers) has been created for Georgian public schools (administration, teachers, and students). Also virtual consulting spaces have been set up in all districts of Georgia where volunteer technology experts from the "New School Model" help teachers implement distance learning. Among the assessed countries Georgia's results were above average (among the first 7 underlined) according to some parameters (quality of digital devices at school; internet band/speed, availability of software; teachers' technical and pedagogical skills; time available for teachers to prepare for digital teaching, effective professional resources for teachers, teachers are provided incentives; the school has qualified technical staff needed for provision of digital learning; and effective online learning support platform is available), and not so good according to other parameters (access to a quiet place for study, to a computer for schoolwork, to a link to the internet).

\subsection{Ukraine}

Safety and health of Ukrainians is a priority. Therefore, relevant Ukrainian Ministries and Services, including the Ministry of Education and Science of Ukraine (2020, February 02) had to take relevant measures in face of COVID-19 pandemic. It, for example, recommended that higher education institutions arrange the possibility of distance learning for students from the People's Republic of China and Southeast Asia countries, who are not currently in Ukraine and/or who cannot arrive in Ukraine due to the spread of coronavirus. The corresponding letter from the Ministry was sent to institutions of higher education on February 3 , 2020. Such measures have been recommended in response to the letter № 283/14-04/2-20 of the Secretary of the National Security and Defense Council of Ukraine from 31.01.2020.

"Our goal is to ensure the continuity of the educational process and, at the same time, take into account all the coronavirus outbreak circumstances (2019-nCoV)," said the Minister of Education and Science of Ukraine Anna Novosad. By February 10, 2020, higher education institutions had to inform all their students and professors from the People's Republic of China and countries of Southeast Asia about the distance learning opportunity and allow them to take the relevant exams after the stabilization of the situation with the coronavirus (2019-nCoV) outbreak (ibid).

All educational institutions in Ukraine have been quarantined since March 12 due to the threat of coronavirus. Initially, it was for three weeks, until April 3, but kindergartens, schools, universities and colleges, both public and private, remain closed for the foreseeable future. As a result, education in Ukraine has gone virtual, and Ukraine's National Online School project announced by President Volodymyr Zelenskyy on March 31 (UNIAN, 2020) - was launched on April 6. 11 different TV channels started broadcasting lessons for schoolchildren from fifth to eleventh grade.

"40 teachers from Kyiv will become teachers for the whole of Ukraine during the quarantine. 11 subjects will be taught remotely," reads a statement about the project's launch. The lessons will also be available on the official web pages of the Ministry of Education and Science of Ukraine on Facebook and YouTube (UNIAN, 2020).

Students from the temporarily occupied territories of Donetsk and Luhansk regions and annexed Crimea will also be able to watch video lessons created within the framework of the project on air, broadcast by the recently launched Dom ("Home") TV channel, the Office of the President clarified on April 2 (Hromadske International, 2020, April 6). Hromadske has taken a look into how education is brought online in the country beyond televised lessons.

\section{School: Urban and Rural}

Lyudmyla Yurchenko is a biology teacher at a gymnasium in Cherkasy, a city in central Ukraine. A month ago, the school had just finished a three-week quarantine announced because of the spread of influenza and SARS. But on March 12, lessons stopped again. Schools have been closed for over five weeks now, but no one knows when the quarantine will end. 
The last long break in high school was in 2008 - when the desks were vacant for a month and a half. Therefore, according to Yurchenko, teachers have little experience of working remotely. Nevertheless, Yurchenko is familiar with it, and uses some tools for distance learning such as The OSHKOLA pilot program, which is an electronic journal where parents and students can keep track of grades and homework, which has been functioning in Cherkasy for over a year. Teachers' communities are already uploading collections of online learning services on Facebook. Most high school teachers have been working with the Google Classroom platform for three years, where they can test, monitor homework, and provide useful videos and presentations. Yurchenko does not shoot her own videos, but she does have a presentation on each topic. Biology experiments have already been recorded by her colleagues.

There are also plans to launch special TV lessons for schoolers in graduating classes in Cherkasy, a practice initiated by Kyiv. This year they should be taking the ZNO (a unified state examination), which has currently not been cancelled. But this has not yet progressed beyond discussion. According to Yurchenko, the main problems are that not everyone is able to film and edit. Many teachers lack the necessary equipment, and it is also difficult to explain some topics remotely. For example, math teachers do not yet know how to work with classes to solve complex math problems without using a board. Despite her e-learning experience, Yurchenko feels anxiety: "Nobody knows how to organize such long-term online learning - we appreciate that this may not end in three weeks."

The teacher states that schoolchildren do not feel responsible when it comes to remote learning: "If teachers were mentally and technically prepared for this situation, we could teach parents and children to take online learning with responsibility. Instead, it is often not taken seriously. It's good if the child is responsible and diligent, but what about the others? Imagine if parents took their child to spend quarantine with their grandparents?"

Yurchenko's colleague, Iryna Valentynivna, works in a rural school in the Cherkasy region. She is of retirement age, but she continues to teach history and is a class manager. In the early days of the quarantine, the school's management had asked teachers to come and check in, but now the system has changed. Teachers over the age of 60 stay at home and the rest come on a daily basis - 1-2 from the entire staff.

Iryna says that even during the previous quarantine, she started using Telegram to communicate with her class. So she continues communicating with her students there. Every day, they write to her about their health, which she reports to the headmaster. Prometheus courses and tests are used for training.

"All of my students have smartphones," says Iryna, "so we don't have any problems. But there are poorer families, there are villages with poor reception, and if their street is "in a hollow" then people have to go up a hill in order to catch at least some reception. In fact, this is always a problem in villages."

She adds that primary school teachers are in the worst position. Every other day, her colleague calls all parents in a class and explains what and how a child should learn and read. However, Iryna believes that these students will have time to make up for what they have missed, but that might not be the case for older students.

\section{Remote Schools in Ukraine: Tips for Parents}

In addition to schools with the usual form of attendance, there are also distance learning schools in Ukraine. Anna Roshchyna is the director of one of them (??). She says that, in general, distance learning in Ukraine is only emerging because there has never been demand for it. Some teachers used some specific tools, but did not apply these practices in general.

Remote education can be synchronous and asynchronous. In the first case, a teacher creates a virtual classroom where they work with all students in real-time. Because this can be expensive and technically difficult, most use an asynchronous 
approach - sending tasks and materials by email or messenger, and it is up to the children to decide how much time to work on them. On the other hand, Anna believes that this approach is less effective because the class often needs control and organization from the outside.

Remote Online School 977 has been around for four years. During this time, Roshchyna realized that the biggest problem was not making a video or making a presentation. The hard part is convincing your child to learn in this format.

"The most important thing for remote education is motivation, control and organization of the process. Most colleagues will find that students do not want to do anything online. This time can be wasted instead of learning," Anna said.

To prevent the child from getting out of step of the educational process, Anna advises parents:

- first of all, to understand that the ability to learn remotely is a useful tool for children in the future, as they will later be able to continue their education or work remotely for international companies;

- to explain this to children - it is possible to agree with them that for the time being, they will work as they will in the future, and this will be useful experience for them;

- to organize a timetable, because in asynchronous distance education, children will receive heaps of information and tasks that are difficult to organize. In this case, planning will help - for example, today the child will study mathematics for an hour, and after a break - English. It is not necessary to start studies at 9 a.m. - let the children do as they see fit.

"In fact, the program of the entire Ukrainian school can be completed in seven years; Therefore, you should not worry that during quarantine, the child will lose time - there is enough time, you just have to plan everything correctly," explains Anna.

Volodymyr Bakhrushyn, a specialist in education policy and an adviser to the Minister of Education and Science, said that remote learning was introduced in Ukraine 20 years ago. There are Regulations on remote learning, but since their adoption in 2013, the system has changed significantly. The document was created to regulate remote education as an individual approach rather than a form of education in all institutions.

"There is a provision in the Regulations that schools must gather a pedagogical council to adopt a remote format of work, some issues need to be coordinated with their parents," Bakhrushyn mentions as one of the shortcomings. "As things stand, it is impossible and dangerous to do so. But since the situation is unplanned, I think these norms can be circumvented through decrees by the Ministry of Education and Science."

Bakhrushyn also notes that some of the clauses were described as a compromise between schools and universities, and as a result, the proposed in the Regulations methods do not suit anyone at all. In addition, the drafting of the Regulations did not take into account the existence of alternative education platforms, such as EdEra or Prometheus. Moreover, according to Bakhrushyn, no one thought that it would be necessary to use remote learning in extreme situations.

Both schools and universities have difficulty transitioning to remote education. Bakrushyn notes that not all universities have the Moodle remote education platform, and online education has been largely an infrequent initiative of individual teachers in schools. But there should not be any difficulties with the ZNO, the expert believes - everyone will be in the same conditions. It may be possible to change the threshold for some subjects, but this is still under discussion at the Ministry.

Currently, Bakhrushyn advises taking courses from EdEra or Prometheus. At the same time, the Ministry of Education and Science broadcasts televised lessons on the Ukrainian parliament TV channel and its own YouTube channel, which will focus on ZNO subjects - namely Biology, Ukrainian language and literature, and History of Ukraine. 
The courses used by the Ministry were developed by the Prometheus platform specifically to prepare for the ZNO even before the introduction of quarantine.

Prometheus co-founder Ivan Prymachenko says that remote education can be as good as traditional education - it all depends on the content. Instead, Ukrainian teachers are now in a situation where they are forced to implement a new for them methodology, without experience and training. Therefore, the team agreed to the proposal of the Ministry of Education and Science to provide its own courses for the parliament.

"We hope the quarantine will end soon, but so long as there is no coronavirus vaccine, it may come back. Maybe in the next two years, this situation with long quarantines will happen again, and we should be ready to learn in such a format," Prymachenko believes.

From the moment of quarantine announcement in Ukraine, the number of registrations for Prometheus courses has increased by $30 \%$, for the ZNO preparation courses - even more. This is an unusual situation for quarantine - usually, students perceive it as extra vacations.

$15 \%$ of those who register on Prometheus complete their studies. The average global figure is just $7 \%$.

"We include a lot of interactive tasks in the course, we make short videos with clear explanations. But the final responsibility for motivation lies with the audience. Learning is difficult, it may not always be fun, but it is necessary to learn. As well as adults, the economic situation in the world is deteriorating due to the coronavirus pandemic, and this is an occasion to learn something new," Prymachenko notes.

Interestingly, Prometheus also has a course on how to create massive open online courses (MOOC).

\section{Universities: Theory and Coordination}

Alina Rudchenko teaches at the Faculty of Journalism at the Vasyl Stus Donetsk National University. This university was relocated from the non-government-controlled Donetsk, and for some time in 2014 the studies were only done remotely. The university uses the Moodle platform to work in such conditions.

Her faculty also makes use of Google Classroom, and students learn digital technology remotely even during the normal educational process. Teachers have devised a new daily plan, they report to the administration, and at the end of the quarantine, everyone should carry out modular examinations.

Rudchenko believes that the main problem with learning during quarantine is the irresponsible attitude to online learning and the inability to use certain tools. But quarantine does not mean that the evaluation system or the number of tasks will change, although the latter can be slightly adjusted.

"For students of the journalism faculty, we have prepared a task where they make infographics about the spread of the coronavirus, analyze fakes about the disease in Ukraine, and make lists of official sources and newsmakers," Rudchenko explains, showing how she is making use of the situation.

Viktoria Kravchenko teaches human anatomy at the Institute of Biology and Medicine at the Taras Shevchenko Kyiv National University. Part of her discipline is theoretical, while another part involves practical work. Three years ago, the Institute of Biology building was closed because of heating problems. Therefore, she has had long-term experience of teaching remotely.

"Prior to the quarantine, my students and I formed groups in Telegram. I sent assignments and links to interesting materials there," recalls Kravchenko. A month ago, she started using Telegram's voting bots for testing. This has now become the main form 
of assessment: the teacher sends the group preparation materials, assigns time for the test, and sets a limited response time. She also uses Google Classroom for remote learning. Students have their own pages where they add completed tasks - for example, copies of anatomical drawings.

"Lectures and seminars are easy to do, the biggest problem is the practical classes," Rudchenko says. In order to somehow remedy the situation, she sends students videos of biological experiments: for example, a study of the behavior of rats - this topic should be studied by students. But it is impossible to learn how to stitch or dissect animals remotely. Rudchenko hopes that if quarantine lasts only for another three weeks, she will simply change her lesson plans, and all the practical work will be done by the students upon their return to university. But if remote learning is extended, she will have to look for another way out. There were no instructions from the university management - teachers act at their discretion. Therefore, a centralized Moodle system is not used for remote learning at the university, which has 25,000 students.

In contrast, the Ukrainian Catholic University in Lviv had no problems adapting to e-learning - its own content management system (CMS) has been in operation for the fourth year running. All students have their own pages in the system where they work with the training courses - previously these were only for certain disciplines, but now the whole educational process has moved there.

Alina Synytska, who runs the UCU's Center for Educational and Innovative Technologies, says that every training program is connected to the CMS. The Center has areas to work with students, with full-time teaching staff and invited lecturers. "Our strategy: the main point of access to training is the CMS," she explains. Preparation for quarantine at UCU began even before its introduction. The first step was to inform students how to protect themselves. The university has set up a working group to form a remote learning process and has conducted additional training for lecturers. The Center continues to advise teachers on remote learning and recommends reading their blog to find helpful tools and platforms.

\subsection{Azerbaijan}

The government of the Republic of Azerbaijan also took some proactive measures in order to prevent coronavirus (COVID-19) outbreak in educational institutions. Starting from March 2, all education-related activities were suspended all over the country by the decision of the operational headquarters under the Azerbaijani Cabinet of Ministers (2020). As a consequence, the novel coronavirus forced educational institutions to go online.

To handle the situation to some degree, the Ministry of Education has offered several types of distance education. On March 11, TV classes named "Lesson Time" were launched on state TV ("Medeniyyet" channel). The lessons mainly cover all classes and briefly explain lesson topics (Ministry of Education of Azerbaijan, 2020, March 11). Additionally, 1621 video lessons have been posted on video.edu.az portal of the Ministry of Education, which is made up of 3D animated videos and Khan Academy classes. With the participation of local and overseas instructors, classes have been prepared based on the national curriculum. To support the TV lessons, on April 2, the Ministry of Education launched the "Virtual School" project, which aims to ensure the interactivity of distance education and to enlarge the opportunities of online teaching (Ministry of Education of Azerbaijan, 2020, March 31).

Concerning the higher education, online lessons started on April 1 with the free use of "Microsoft Teams" platform that has been created by the Ministry of Education of Azerbaijan to set the distance education process. The platform lets teachers provide distance teaching mainly via video connection. It also creates an opportunity to use interactive features, to set teacherlearner discussions, to upload and transfer various lesson materials (larger materials as well), to schedule online lessons with the help of calendar tool, to set group work and use assessment feature (Ministry of Education of Azerbaijan, 2020, April 1). 
Besides, some non-profit organizations in the country have also offered several educational resources on their website. UNICEF Azerbaijan launched some initiatives on its website, Facebook, Instagram, and YouTube, which includes helpful suggestions and tips for parents who stay at home with children during COVID-19 quarantine (UNICEF Azerbaijan, 2020). Similarly, British Council Azerbaijan offered the best of its online resources and platforms for different types of learners to contribute to Azerbaijani education in this period (British Council Azerbaijan, 2020).

Theoretically, the concept of distance learning is not new in Azerbaijani education. Adopted in 2009, distance education was recognized as a form of education in the Law of the Republic of Azerbaijan. About Education (2009). It is defined as "a type of education where the teaching process is organized through electronic, telecommunications, software, and technical tools" (article 1.09). Yet, the mechanisms for its implementation in the country have not been developed sufficiently. For this reason, the introduction of distance education is not yet a priority in the educational process of the country (Aliyeva \& Rzayeva, 2019). In their recent study, Karimova and Garibli (2019) listed some challenges regarding the distance education in Azerbaijan that need to be taken into account:

- features, principles, and peculiarities of distance education need to be determined more clearly;

- requirement for the content, forms, educational and methodological assistance of distance education have to be developed;

- principles of managing the process of distance education need to be set out;

- regulatory basis needs to be improved;

- certification of educational institutes of distance learning must be provided;

- the fact that not all disciplines can be taught and trained via distance education has to be taken into consideration.

Despite technological opportunities that were offered by the Azerbaijani government in order to provide distancelearning, its effectiveness has come into question. Needless to say that distance learning demands organization of the educational process and not to mention different teaching approaches compared to traditional methods. Karimova and Garibli (2019) state that teachers in Azerbaijan are not adequately qualified for online teaching, and even many of them still prefer traditional teaching methods. According to hafta.az (2020, April 9), educational institutions in Azerbaijan are not ready for online education during COVID-19 quarantine due to a lack of inadequate technological resources. On top of that, approximately 150000 teachers in Azerbaijan do not have the competence to manage these technical capabilities.

In order to use technologies and platforms that were offered in the novel coronavirus period, the Ministry of Education has prepared short video-instructions both for teachers and learners and posted them on the video lessons portal (video.edu.az) (Ministry of Education of Azerbaijan, 2020 April 1). Nevertheless, not it will take time not only for teachers to learn about new technologies, but also for teachers and students to be able to apply them practically effectively and with ease. Therefore, to ensure the mobility of the projects prepared in the novel coronavirus period in Azerbaijan, teachers' attitudes towards the introduction of distance-learning needs to be analyzed.

\subsection{Iraq}

\section{Pre-Pandemic Education}

It goes without saying that Iraq has been a war-zone area for decades; this surely affects all aspects of life negatively, including education. 
The global organizations and associations have started supporting the Ministry of Higher Education and Academic Research and the Ministry of Education with programs and have made agreements on different levels in an attempt to fill the gap that war with its terrible consequences caused to learners, teaching staff, and the educational institutions as well.

As the world nowadays lives in the age of technology and information systems in all fields and sciences, a ministerial order (Numbered 1205 of April 5, 2015 ) was approved by the Iraqi Ministry of Higher Education and Academic Research to form a high-level committee for virtual learning in the Ministry Center. The main goal of this committee is to come up with strategies of virtual learning to be operationalized in Iraqi Higher Education. Besides, the Minister of Higher Education approved the Scientific and Technological Information Center activation in the Iraqi Commission for Computing for virtual learning according to the Ministerial Letter Numbered B.T. 2/1704 of March 5, 2015). This is the departure point of virtual learning in Iraqi education (Al-Juboori, 2020, p.1). Let it be known, though Iraqi Ministry attempts should be definitely praised, the political situation in Iraq at that particular critical period was not promising - three Governorates, namely: Nineveh, Salaahudeen , and Al-Anbaar, were occupied by ISIS leaving Iraq and education cut into pieces.

It is worth noting that attempts have never stopped as the Ministry added the Item Google Classroom with grade to the Staff Members' Annual Assessment recently as a way of promoting the staff to adopt such up-to-date manoeuvers in teaching university students.

Viewing the appropriateness, validity, and degree of application across the colleges in Iraqi universities sounds questionable. Let us take the University of Mosul as a case in point. According to my personal experience as a staff member at the Dept. of English, College of Arts, I started adopting Google Classroom in the academic year 2018-2019. It was the Research Methods Class for the Third -Stage while posting some files as materials for the students. I could say it worked for me a little bit better than the traditional class in saving time only. Very few colleagues did so. In contrast, the majority of scientific colleges, if not all, have adopted Google Classroom in the classroom posting assignments and drills, so as to encourage students to use technology. To be noted, the staff at the colleges of humanity are a bit far away in making use of technology in the educational process, if compared with their peers in the scientific colleges; the staff and even students there are more aware of technology, computer software and online platforms. I guarantee that this is one of the reasons behind the remarkable way in adopting the classes after COVID-19 pandemic as far as the scientific colleges are concerned, leaving the colleges of humanity somehow in the back, although some staff are experts in technology and computers. Undoubtedly, their experience supported them after the pandemic started in adopting distance learning.

As for research, academics and experts have conducted studies focusing on virtual learning and its degree of application in Iraqi educational institutions (school and universities), comparing traditional and blended classes, i.e., adopting both traditional and virtual methods of learning. Hasan and Hmood (2009), staff members at the College of Engineering in Al-Mustansirya University, Baghdad, Iraq conducted a study comparing traditional and e-learning. The two authors suggested the necessary means and tools which can help to transfer the learning system from traditional learning to e- learning, coming up with teachers and students' views given in a questionnaire. Still, I do not fully agree with their conclusion that "education system in Iraq is ready to accept and deal with the e-learning technology" (p.487). In other studies, like Al-Qazzaz (2014), it is concluded that Iraq lacks the foundation to apply distance learning in educational settings.

From a psychological perspective, Al-Mayaali and Al-Hijamami (2009), at the College of Education for Girls, in Al-Kuffa University, Iraq conducted another study where problems of applying the distance learning in Iraq is the core of their questionnaire-based study. Teachers and students were recruited and results showed problems facing teachers and students while doing distance learning as a new educational technique. 
Of the Technical Institute in the University of Kirkuk, Iraq, Othman and Kareem (2014), proposed a questionnaire-based study assessing the faculty members' skills in the light of the use of e-learning techniques in the educational process. The authors' results showed that "most of the faculty members lack the necessary skills to use these techniques and the unfamiliarity with the skills to use software. The research ended up with a recommendation which echoed "a proposal of e-learning program to activate the training project for faculty member[s]" (p.154).

A good movement towards holding workshops and training sessions on distance learning was clearly noticed in the majority of Iraqi universities (public and private), even years before coronavirus pandemic.

As a staff Member and A Director of the Ongoing Education Unit in the College of Arts, the University of Mosul, Iraq, it sounded legitimate to start investigating the issue of distance learning in my spot, tentatively including my experience. In a research project entitled "Not Too googlish! Google Classroom in the Authors' Eyes Accompanying My Pros, Cons, and Sighs!" (in preparation) which I started on December 2019 subconsciously being aware of the coronavirus pandemic beginning. My core goal is tracing back the contribution of authors, especially the Pros and Cons of e-learning in the literature and bringing to the stage me and my experience with the students and Google classroom focusing on such queries:

1. What is Google Classroom?

2. Does Google Classrooms have the potential for students, teachers, and faculties?

3. What are the Pros and Cons of Google Classroom magnified in the literature?

4. Could virtual classroom be proper complementarity for the traditional classroom in the current Iraqi higher education?

5. In what ways do instructors and students use Google Classroom?

6. How do instructors and practitioners trace students' engagement in Google Classroom?

7. What factors stimulate teachers to use Google Classroom?

8. How do teachers use Google Classroom in their teaching?

9. What are the barriers to use Google Classroom?

10. What are the students' viewpoints to Google Classroom?

To this point, I should refer to the fact that in spite of some programs initiated in cooperation with global organizations, distance learning was not fully adopted in all Iraqi schools (whether public or private in all cities. In rural areas not all schools can carry it out due to problems with electricity and the internet. I have come up with some indications about promoting e-learning in the Ministry of Education in Al-Qazzaz's study (2014, p.83-85) where some steps were taken by the ministry in distributing various educational packs including kits, materials, and means to support teachers and students. Still, it remains just blended learning in the Iraqi educational institutions.

In November 2019 there were protests in Baghdad which then covered other cities in the mid and south of Iraq. There were no courses or classes, as students refused to join all the educational institutions. This is another reason for promoting distance learning in Iraq, besides the coronavirus pandemic. Could it be justifiable and workable?

\section{While-Pandemic Education}

Iraq and education are currently in a bad situation. There was a gap in the annual calendar of the present academic year, meanwhile we found ourselves in the hoopla of coronavirus pandemic unprepared to face and keep up our educational missions. 
It was the end of the Spring Holiday (on Feb 7-16, 2020), when the Iraqi Mayors stated partial curfews and social distancing in cities. Yet, all students and staff members, teachers, and kids were not allowed to attend educational institutions. A full closure of educational institutions was announced by the government in Iraq on March 17, 2020. A place like Iraq - a place for war game - is surely unprepared to manage such a crisis.

Although this is the case, the Ministry of Higher Education and Academic Research played a role in controlling the situation in one way or another. The Ministerial Letter (Numbered Th.M1/2059 of March 28th, 2020 obliged all the universities in the cities where there were no demonstrations to switch to distance learning in the second course. Then, the Ministerial Order covered all institutions in the Ministry authority to choose the appropriate platforms for distance learning in an attempt to facilitate the process of learning (http://mohesr.gov.iq/ar/).

The staff members began discovering Google Classrooms, as the majority of them had not used them before. Facing problems of opening gmail accounts for that, opening a class, starting posting materials, assignments, using YouTube, Word and PDF files and all other technological things that teachers know nothing about, especially at Colleges of Humanities. At the University of Mosul where I work, workshops on e-learning have been held online. The University of Mosul Presidency is supporting the teaching staff by platforms like Zoom and Meet to keep up the academic activities like workshops, sessions, and seminars. The University Presidency is encouraging the students to join virtual classes. A schedule was distributed to both staff members and students in order not to let the students be in a mess. All the technological tools are suggested to be posted on the virtual class, whether videos, PowerPoint presentations, Word and PDF files, using Meet and Zoom platforms. This is an alternative to face-to-face interaction in the traditional physical classroom. Assignments were given to the students and graded upon fulfilment. No exams are held.

Two students who live in Baghdad were frank enough to speak to the media describing e- learning in Iraq after Corona Virus pandemic as "Corona Distress" (https://www.aljazeera.net/news/cultureandart/2020/3/25). One student at the College of Engineering argues that under the current situation, e-learning is unsuccessful and unworkable. He continues:

- "I cannot get benefit from the scientific material via the internet as I cannot accept the idea of substituting the teacher with the computer machine. The majority of teachers post their lectures on the class [referring to Google Classroom] and they disappear. Many questions spring to mind yet I could not have an answer. I will not spill the beans, if I tell you that I feel hopeless about my academic future".

Another student, from the College of Pharmacy, also seems anti e-learning, focusing on a very pivotal point in teaching / learning process which is the face-to-face interaction between teacher and student, saying that

- "Teacher-student face-to-face interaction is missing in e-learning and this affects negatively comprehending the scientific material on the part of the student".

From the student perspective, he named some other reasons of not accepting the idea of Google Classroom, such as:

- "...lacking the visual and sentimental interaction and the explanatory discussions in Google classroom leading to the absence of students' competition".

As a staff member at the University of Mosul, Iraq sharing all global colleagues' e-learning experience at this difficult unrestful time, I am in contact with my students via social media. In an attempt to assess Google Classroom experience, I raised four questions tentatively to some undergraduate and postgraduate students at the University of Mosul, see the following:

Q.1. Do you believe that Google Classroom and the uploaded platforms are helpful now compared to physical classroom? (Give your reasons) 
Q.2. Is Google Classroom fruitful in all your syllabi?

Q.3.How could you assess your performance in Google Classroom?

Q.4.What is the percentage of Google Classroom appropriateness during coronavirus pandemic?

And here we have the responses:

Student 1

Q1. No, I think that Google classroom does not do it alone for a number of reasons:

1 - Internet speed is not good in Iraq So, this is an obstacle to downloading files.

2 - There are many students who do not have internet mainly so this prevents them from obtaining files.

3 - E-learning is a new system for students and they have no experience dealing with it (They don't even know how to download files). There are many other reasons ... but these are the main reasons.

Q2. No, there are some curricula that require direct communication between the professor and the student to understand the subject ...Such as grammar, poetry and French,

Q3. Not fairly good ...Because I can't understand everything. Because I can't understand everything.

Q4. I give it 50\% right now.

(Source: Social Media, APR 8, 2020, 9:49 PM)

Student 2

Q.1. I think it's the only way to receive the lectures, we don't really have any other choice. It's not as good as the real physical classroom because student can't act or interval during the lecture. However, teachers can change that by organizing the lectures, giving recorded lectures or videos and at the end of each week teachers can give life lectures to discuss the material that is given during the week.

Q.2. I don't think it's really fruitful to all of the syllabus.

Q.3. I am trying to be better since it's the first time for me to organize my time and trying to chat up with the lectures that are given. I don't want to lie to you but sometimes I feel that I'm completely lost, but beside Google classrooms I try to find my way through the internet because being the tutor of yourself is not an easy thing to do.

Q.4. I would say $40 \%$.

(Source: Social Media, APR 8, 2020, 5:11 PM)

Student 3:

Q1. In my point of view, attendance physically is better than studying online. The professors copy a sites from the net and asks us to understand, study and prepare it, so most of the responsibility falls on students, so most of the student solve the homework even without knowing what's going on. Except for the few teachers who work hard to explain the material to the student in different ways, such as sending his explanation in video or voice. We are, I mean, this generation, need methods that attract us to interest in education.

Q2.We cannot say that it is fruitful in all curricula, as there are materials that need to be practiced practically. 
Q3. I'm trying to do my best to keep up with Google Classroom but I don't feel that I'm learning and getting useful information that I have to get, especially that I'm in my senior year and I have to work on myself.

Q4. Well, we can say that the percentage is $50 \%$. because In this case, and with the spread of Corona virus, we cannot go to college and socialize with people, so it is a good way for this period, but it is not as useful as physical classroom.

(Source: Social Media, APR 09, 2020, 8:31 PM)

Student 4:

Q1. Definitely not, there is a big difference between Google Classroom and the physical one because education in general is a process of interaction between the students and the teacher in the class. So, the students should react directly with the teacher not behind the screens. But now in this circumstance it is better than nothing.

Q2. Actually, it depends on giving the lecture as well as on the lecturer and his/her way of teaching. If the lecturer smart and knows very well how to give important information to the students. So, she/he will give all the required syllabus.

Q3. It is not bad, because I do not have a connection with the lecturer.

Q4: 20\%. Just for homework not for presenting the whole lecture.

(Source: Social Media, APR 08, 2020, 9:42 PM)

Student 5:

Q 1. Definitely not useful, for several reasons:

- Only PDF lectures, there are no explanatory videos from the teachers.

- The absence of a specific schedule of lectures, teachers choose inappropriate timing.

- Difficulty in communicating with teachers to answer inquiries and discussion with the exams will be a group fraud and useless at all. There will be also injustice to some students.

- Most importantly of all that I mentioned, I'm convinced that the matter is not serious, because we have not use this system before.

Q 2. No, not all fruitful.

Q 3. My performance in Google Classroom is a bit good, but not better than the physical Classroom.

4. The percentage is $10 \%$

(Source: Social Media, APR 08, 2020, 5:20 PM)

Student 6:

Q1. They are good, but not in comparison with the usual way. Because of our ability as students to focus. And because of internet connection problems.

Q2. No, it is not specially in practical lessons such as design.

Q3. I tried very hard to study and to follow every assignment but the amount of information that I got is very low. So I have to say very weak.

Q4. 30\% just for taking a look about our lesson nothing more.

(Source: Social Media, APR12, 2020, 1:52 PM) 
To sum up, distance learning, e- learning, or whatever it is called, is a controversial issue in Iraq, not because people' lives are at stake due to coronavirus pandemic and e-learning has no alternative at the moment. The issue is in need for further investigations as the trio economic - political - educational state of Iraq could be the main reason behind the inappropriateness of adopting e-learning, even if adopted due to natural circumstances.

Readers may kindly notice that the efforts of the University of Mosul Presidency are prominent in updating the academia and supporting both the students and the staff with scientific manoeuvres as much as possible, before and during the coronavirus pandemic. As an academic and a staff member in such a renowned university as the University of Mosul, I am appealing the globe to support education there whether electronically or not!

\subsection{UK}

Although (or, maybe, because) UK government introduced strict measures of protection against the coronavirus when the pandemic was full ahead, without any official demand, some school were preparing to go online: selecting resources, training teachers and students to use the technology (Busby, 2020), which gave them a certain advantage when they had to go online. It was parents who heeded calls not to send children to schools (BBC, 23.03.2020) which eventually pushed the government to make a corresponding decision. Many universities, even the medical faculties where onsite classes are so important, also made the decision to end in-person lectures autonomously (The Guardian, 2020, March 12), without waiting for the government to tell them do so. This is what is called bottom-up management and democracy in education.

In the UK, the COVID-19 crisis has seen many education experts scrambling to 'keep safe' after being warned and following the official lockdown on all public gathering, education inclusive. Department for Education (2020.07.04) released a rule that affects all aspects of education from cradle to higher education institutions to obey the lockdown and only open their doors to children of critical workers and vulnerable learners. The strategy that is widely accepted is to maximize the use of distance learning to continue to deliver education to learners. Many education providers have had some form of use of the distance learning especially through online learning to administer learning but now are faced with the dire responsibility to brace up with the challenge of using online learning software applications or systems.

Concerning the previous experience of formal distance learning, it is necessary to note that the UK has a half-century long and extensive experience of distance learning. The Open University UK is the only university in the UK dedicated to distance learning which has structured strategies to meet the needs of learners online (The Open Univerity UK, n.d). Since its establishment in 1969, the university has proven to educate people using exceptional means and methods. It is a university open to people, places, methods and ideas (Crowther, 1969). The UK through the Open University over five decades experienced much more advancement as it was run at low cost, without devaluing the quality of education as proven in its educational materials and administered its content using different communication technologies.

One of such great education databases is the website futurelearn.com. It is with this impact and inspiration that many other universities and schools began to offer courses online either as part time, full time or through other distant learning strategies. This means that learners do not actually have to be in a class at the designated time, studying, but can be in the comfort of their homes, at work or in a recreational area with spare time, reading or studying at their own pace, and with the advantage of contacting tutors and still be assessed and get certified in the programs they have applied to.

However, distance learning is not as well appreciated politically compared to onsite learning in the UK. Online teaching experts and administrators have experienced being treated as second-class educators until the COVID-19 crisis, which has made the whole system turn to distance learning as a rescue (Weller, 2020). Many schools (including nursery ones) are not well prepared for such a situation that requires social distancing and so have to work with parents to get children to still be getting one form of 
education or the other. The strategy basically is to send assignments or reading materials through emails to parents who in turn have to guide and ensure the children are really studying.

Other schools who had been tech savvy using software applications that aid teaching or useful for internal and external administrative purposes like Sims, CMIS, and Bromcom are now turning to more virtual schools. Online course providers and teachers enthusiastic about social media still use other social media platforms to connect with the pupils, like Google +, Edmodo, TedEd, Pinterest, WordPress etc. either directly or indirectly. However; often times these are done with caution with the safeguarding team monitoring their activities. Other well-funded and equipped schools are strategizing on how to teach online using webinars and podcasts, live broadcasts. Other universities are turning to MOOCs and training up with CILT Teaching Online Portal. Whilst all these are on; education organizations like Pearson, the British Council, Education and Training Foundation (ETF), among others, are doubling their efforts in reeling out courses that teachers and school administrators can take to prepare them for the next terms or semester in online teaching.

Pearson, for example, is giving universities free access to their core educational resources and English language online resources as well, one of the BBC's core aim during the Covid-19 crisis is to "help people especially in the UK by providing advice education and support through their live programmes on TV and Radio, the British council opens all the materials the LearnEnglish website to all people not just in the UK but all over the world to have access to for self-study and for free and ETF is offering webinars for the build-up of education practitioners and their learners in online learning for free (Pearson, n.d; BBC, 2020; British Council, n.d; Education and Trainng Foundation, 2020).

With that said, speculators and spectators monitoring events are also trying to see what is in order and what seems to be falling out of place. David (2020) is of the opinion that many teachers are not as keen to be updated on the technical software or online social skills to be able to use the strategy in mitigating the effect of the crisis on the education of students. While online programmes are great for upskilling teachers, they also pose a burden for many of them (especially the older generation) who have mastered teaching on site and are equipped with teaching tools and basic modern technology and software. Having to relearn or even unlearn skills for teaching seems to be a herculean task. On top of this, Hall (2020) reflects that this is time of instability and most teachers are busy looking out for their families and friends and will not want to be bothered by preparing materials for consumption online or setting up webcams to meet with students.

From a safeguarding point of view, Hall (2020) stresses that it may be a bit too far for teachers to embark on live streaming classes reasons being that it has many complications. Some of these complications could be that many issues may be taken for granted which could be a cause for concern like immodest dressing of either teacher or students being taught, the seclusion of students in their bedroom rather than open air where they can be monitored by parents, no documentation of live classes so activities can't be monitored, and immodest use of languages either from teacher or students, lack of technical facilities or broadband for homes who are not well to do among other concerns.

What makes it definitely easier for the UK and other English-speaking countries to develop e-learning these days is that there are abundant educational materials available online in English. And. of course, the experience and the clear legal status of distance learning makes it easier to make decisions.

As due to distance learning, especially for primary schoolchildren, parental support has become especially important, the Department for Education (DFE) among other support measures has provided a database of sites where parents can have access to educational contents that they can have access to help in the tutelage of their children. DFE in collaboration with the UK government continues to provide funding for schools, institutions and workers in general through numerous means such as the Dedicated Schools Grant (DSG), rate relief beneficial to businesses pertaining to education, early years and children's social care 
sectors through business rate system and Coronavirus Job Retention Scheme (CJRS) (Department for Education, 2020 07.04; 2020.17.04).

Whatever the support and the preliminary preparation, the process of going online has been connected with lots of challenges for students, parents, and teachers. According to The Guardian (2020, March 26) "the sites are crashing and lecturers are struggling to turn face-to-face interactions into online discussions". "We don't all log on at the same time as some don't have stable enough internet connection for live chats. Everything is slower." A lot of technical issues like how to hold tests and exams have to be solved, and there are pedagogical and psychological issues to deal with. And, before somebody else helps them, teachers and students try to support each other and develop tips, such as:

- Create as study area and keep it tidy.

- Keep socializing.

- Reach out for help.

- Manage your time.

- Plan your day.

- Be clear when messaging your colleagues.

And the results are good: "It seems hiding behind the screen brings out confidence in our generation" (ibid).

\subsection{Nigeria}

Nigeria has been involved with distance learning for quite a while. Distance learning used to be a fashionable concept of getting further education as early as the 1930s, as students at that time took courses from British Universities which were delivered by post and further down the line, school leavers received education via correspondence in preparation towards the General Certificate Education (GCE) (Obilade, 2012; Ajadi, Olatunde, \& Adeoye, 2008). It was not until 1950, after the establishment of the first University in Nigeria, the University of Ibadan, that indigenous distance learning education was introduced. The University of Ibadan reeled out part-time courses in its Faculty of Education.

However, the Federal Radio Corporation of Nigeria established earlier 1933 during the British Colonial era had been doing foreign programmes which listeners benefitted from and then, after Nigeria's independence, there was the distance learning programme teaching English on the radio. It was renamed the Nigerian Broadcasting Service broadcasting radio to five states in Nigeria in 1950. The same year the University of Ibadan began its first part-time programme. Soon afterwards, other universities began springing up with programmes either done as part-time with tutors teaching learners 'face to face', through recorded audio lessons and print media posted to the learners. Much later did they begin to learn through video cassettes and much recently - through multimedia.

Today, 11 Universities have established distant learning centres apart from the National Open Universities of Nigeria, part of which runs as either open learning, distance learning or dual-mode, though, about 30 universities have sought for NUC's license to operate the dual learning mode (Lawal, 2020; National Universities Commission, n.d). The National Open University of Nigeria claims to be the perfect university which runs full-fledged distant learning programmes, administration with strategies combining face-to-face, learner-centred, technology-supported and interactive modes of study and boast of 78 Study Centres located in different parts of the country with more than 500,000 students in demography (National Open University of Nigeria (NOUN), n.d; Ikenwa, 1999).

Whilst Nigeria is stepping up in the business of distance learning in education, there are a few factors that prove difficult for the students to get the best of the available education which are lack of accessible updated technology and equipment, 
unstable electrical power supply, limited access to the internet due to high charges by providers, and student financial challenges, and lower regard of online certification in pari passu with the conventional learning (i.e. face-to-face) mode.

With the COVID-19 Lockdown, all universities, colleges and school- administration including NOUN is on a standstill. Every educational institution has followed the directive of the Federal Government of Nigeria and Federal Ministry of Education and so all workers including those working in the education sector have ceased work operations, however, NOUN still encourages all her students to make use of the online facilitation sessions provided in the form of video conferencing, discussion forums and chat sessions with other students for each course. These platforms are only available for teachers and students (Economic Confidential, 2020; National Open University of Nigeria (NOUN), n.d; Federal Ministry of Education of Nigeria, 2020).

With much ado for mitigating this crisis, Reimers \& Schleicher (Bodreau, 2020) gave a 25 point checklist for education providers to respond to the COVID-19 crisis, but the critical questions that are to be asked are: is the education systems of Nigeria prepared to meet up with this strategy? Do we have schools, colleges and universities that already have a system in place where such ideas can just become automated? Are education administrations or administrators skilled enough or become internet savvy to be able to map out the strategy for teachers to follow and finally at the bottom of the funnel, are teachers motivated or trained to take up online teaching?

In an interview, Prof. Jegede, the first Vice-Chancellor of NOUN, explained that many states in Nigeria such as Lagos, Ogun, Oyo, Borno, and Kaduna have found online learning as a major solution to the COVID-19 pandemic. Online learning or elearning or open distance and electronic learning (ODeL) will become normalized as the medium of education in the country as a result, though Nigeria still has a lot to grapple with when it comes to distance learning education. Nevertheless, there are great prospects for the country as there are other ways to tackle the problems like the use of solar energy and enabling students to access their learning through their mobile phones (Lawal, 2020).

The Commonwealth of Learning (COL), an inter-governmental organisation has opened a great opportunity for member states (including Nigeria) to benefit from its wealth of online educational resources as well as a list of other links which could be accessed mostly free of charge by students, parents, policymakers, schools and further education institutions likewise (CommonWealth of Learning, 2020). Also, there are a couple of organizations that are stepping in to the rescue of education, especially during COVID-19 pandemic, which are Education in Emergency Working Group (EIEWG), UNICEF, Save the Children amongst others. For example, the EIEWG in Nigeria is closely working with the Humanitarian Country Team, the Federal Ministry of Education of Nigeria and the Global Education Cluster (GEC). Their objective is to curtail the effect of the COVID-19 crisis in the North-Eastern Part of Nigeria mostly seen as the most vulnerable area by preventing the spread, and transmission of the virus among learners, parents and teachers; reduce the impact of learning standstill and improve the wellbeing of learners, teachers, parents and SBMC using alternative methods; and finally, to ensure inclusion and safe return of learners, teachers and SBMC through awareness on the COVID-19 and how it could be transmitted, updates on the situation of the virus and impact in the country and the world, continual education through, homeschooling, distance education through all means available including the radio and adequate funding for teachers and local schools who will be displaced in the course of the crisis (Education In Emergency Working Group (EIEWG), 2020).

Will the education system, universities and school administration be able to cope with the whole concept of distance learning should the lockdown continue as a result of COVID-19? That answer can only be given when the respectable authorities give distance learning the priority it deserves. 


\section{Method}

\subsection{Research goal}

The goal of this research is by no means to criticize any educational institution or system of education (country), it is just to find out how prepared we happened to be for the need of prolonged total digital education and whether teachers really are at least 'digital immigrants' and students - 'digital citizens'. We believe that the obtained results should be first of all useful for educational policy makers in order to improve the availability / quality of distance learning and in case of repeated need of switching over to totally distance learning like in spring 2020 , so that educators meet the challenge better prepared than now.

\subsection{Research participants and ways of reaching them}

Research population is all school and university teachers of the countries under study. To hold a representative study is probably only in the power of Ministry of Education, Science, Culture and Sport of Georgia or whatever the name is in other countries (and even they may nowadays be unable to do so unless teachers respond, as nobody can oblige them respond). The Georgian Ministry (https://forms.office.com/Pages/ResponsePage.aspx?id=POnSYT1CtEOPIxWAwjQZUh5jg-i1E-

JCjQOSNmsaln1UREZJQk45RTJUSDY3TDkyRjNJQ1I3SFQxSS4u\&fbclid=IwAR2cWlle_UQm8TqhvGUIhZ7Km3dPbJHvLnNur99kyjB 7FI5pKCJeeav0yXo), for instance, offered a questionnaire to school teachers which only asked whether they wish / can deliver eteaching, to find out the minimum information urgently needed (whether schools could provide it), as result Teleskola (TV-school) was introduced Ministry of Education, Science, Culture and Sport of Georgia, March 24, 2020). We believe that such research was needed for solving practical purposes, but is insufficient for further development of education system. So we hope that our research will provide some more useful information.

Our research was anonymous and confidential and thus will in no way harm any respondent. All participants were voluntary. In the existing conditions, naturally, they were addressed online, via researchers' e-mail, social network, and some professional groups on social networks. Of course, online research has its limitations (Wishard \& Tomas, 2015; Zimmerman, Bos, Olson \& Olson, 2009), such as lack of knowledge whether the respondent is really the one $s /$ he claims to be, but more traditional ways of addressing the target audience were not available in the situation.

In electronically done research it is difficult to speak about participants' selection, as the questionnaire is offered and those who volunteer to participate do so. Initially, the questionnaire was placed on the Research Gate (https://www.researchgate.net/publication/340273381_How_viral_distance_learning_is) academia (https://www.academia.edu/42354076/How_viral_distance_learning_is), as well as the authors' social networks. Unfortunately, although much effort had been made, participants were not too numerous, so we had to address our real-life and social network friends to help us have more respondents. At least, we did our best to represent various strata (school / university and three age groups), to hear the voices of all these groups and in this way to make the survey results relatively generalizable. We did not, however, include the strata of urban/rural schools as an item in the questionnaire, as we expected that teachers from few rural schools would take part in it due to technical reasons (internet availability). Also, asking questions about working in private/public educational institutions and regions of the country would complicate the calculations, however, in the future it is desirable to deal with these groups as well. Some teachers themselves, without being asked mentioned that they were from private/public institutions, village or particular town, so it is possible to judge about the variety of the respondents.

Tables 1 and 2 provide the information about the respondents. Respondents from other than Azerbaijan, Georgia, Iraq, Nigeria and the UK, and Ukraine countries were few, so we included their responses just to represent the worldwide mosaic, but their results are far from generalizable. 
Table 1. Participants of case studies

\begin{tabular}{|c|c|c|c|c|c|c|}
\hline $\begin{array}{l}\text { Countries / } \\
\text { categories }\end{array}$ & Georgia & Iraq & Azerbaijan & Ukraine & UK & Nigeria \\
\hline School teachers & 75 & 20 & 20 & 12 & 14 & 121 \\
\hline University teachers & 57 & 27 & 15 & 21 & 6 & 8 \\
\hline Aged under 30 & 25 & 10 & 10 & 6 & 0 & 14 \\
\hline $\begin{array}{l}\text { Aged between } 31 \\
\text { and } 50\end{array}$ & 67 & 26 & 13 & 21 & 10 & 100 \\
\hline Aged above 50 & 39 & 11 & 11 & 6 & 10 & 15 \\
\hline Total number & 132 & 47 & 35 & 33 & 20 & 129 \\
\hline
\end{tabular}

Table 2. Participants from various countries

\begin{tabular}{|c|c|c|c|c|c|c|}
\hline Countries / categories & US & Canada & Hungary & Iran & Romania & Mexico \\
\hline School teachers & 1 & 0 & 1 & 0 & 0 & 0 \\
\hline University teachers & 1 & 3 & 0 & 1 & 1 & 1 \\
\hline Aged under 30 & 0 & 0 & 1 & 0 & 0 & 0 \\
\hline Aged between 31 and 50 & 1 & 3 & 0 & 0 & 0 & 0 \\
\hline Aged above 50 & 1 & 0 & 0 & 1 & 1 & 1 \\
\hline Total number & 2 & 3 & 1 & 1 & 1 & 1 \\
\hline
\end{tabular}

The number of teachers from other countries is obviously not enough for any statistical treatment, even simple one, but their responses are somehow useful to compare them with other answers and to have an idea of a general picture.

\subsection{Research method}

We tried to obtain objective (however, due to the circumstances, non-generalizable) results, so teachers' observations (inductive reasoning) over the ongoing processes were applied. To find them out, quantitative (non-experimental) method was used, and a closed-ended questionnaire was developed for the purpose. 


\subsection{Research tool}

A questionnaire including, besides demographic information, eight items dealing with teachers' views on teachers' readiness for distance learning was made up. Teachers' and - in their view - students' readiness was assessed from technical, pedagogical and (for teachers) psychological viewpoints. To make it up, we analyzed Markle, 2016; Rafferty, Jimmieson, \& Armenakis, 2013; Trapitsin, Granichin, Granichina and Zharova, 2018) studies.

The items in the questionnaire were piloted and standardized with 10 colleagues - school and university teachers who were not part of the research. They have be assessed in a 6-point Likert scale, according to the recommendation that the neutral answer (neither/nor) should not be placed in the central position (Rinker, 2014). Then the obtained data that include the mean, mode(s) and standard deviation were summed up, presented and analyzed in section 3.3.3.

\subsubsection{Research procedure and ethics}

Applying digital online questionnaire would have, of course, make the procedure of filling in absolutely anonymous, simpler and faster. However, in that case filters for three parameters (country, school/university, and age group) would not work and analysis according to strata would be impossible. This is why the questionnaire was placed on social media and sent to some potential respondents by messenger and/or e-mail). To fill it in, the respondents needed to download the file, mark the relevant for them answers, and send it back to the researchers. For the readers of this article, of course, their participation is anonymous, while in the researchers' file their questionnaires were coded as country. school. below30, country. school.1-50, country. school. above 50 and country. univ. below30, country.univ.1-50, country. univ.above 50, which made them confidential. All participants were, of course, volunteer. A note in the beginning of the questionnaire explained to them the goal of the research and the confidentiality of information.

\subsubsection{Research results}

Research results are presented in tables 3 and 4 .

Table 3. School / university teachers' results: Georgia, Iraq, Azerbaijan, Ukraine, UK and Nigeria

\begin{tabular}{|c|c|c|c|c|c|c|c|c|c|c|c|c|c|}
\hline \multirow{2}{*}{$\begin{array}{c}\text { Countries/ } \\
\text { Items }\end{array}$} & \multirow{2}{*}{$\begin{array}{l}\text { Data } \\
\text { school/university }\end{array}$} & \multicolumn{2}{|c|}{ Georgia } & \multicolumn{2}{|l|}{ Iraq } & \multicolumn{2}{|c|}{ Azerbaijan } & \multicolumn{2}{|c|}{ Ukraine } & \multicolumn{2}{|l|}{ UK } & \multicolumn{2}{|c|}{ Nigeria } \\
\hline & & $\mathrm{s}$ & u & S & U & S & U & $\mathrm{s}$ & u & $\mathrm{s}$ & U & $\mathrm{s}$ & u \\
\hline \multirow[t]{3}{*}{$1^{*}$} & Mean & 3.57 & 3.86 & 4.35 & 4.07 & 3.85 & 3.07 & 4.00 & 4.43 & 2.86 & 3.0 & 4.24 & 4.25 \\
\hline & Mode & 4 & 4 & 6 & 5 & 5 & 3 & 4 & 6 & 2 & 2 & 5 & 4 \\
\hline & standard dev. & 1.55 & 1.38 & 1.80 & 1.49 & 1.50 & 0.70 & 0.82 & 1.90 & 1.68 & 1.73 & 1.88 & 1.04 \\
\hline \multirow[t]{3}{*}{2.} & Mean & 4.00 & 3.42 & 1.82 & 2.59 & 3.80 & 3.13 & 2.25 & 2.57 & 3.86 & 3.67 & 2.96 & 2.38 \\
\hline & Mode & 4 & 4 & 2 & 1 & 4 & 2 & 2 & 2 & 4 & 4 & 2 & 1 \\
\hline & standard dev. & 1.33 & 1.58 & 0.81 & 1.42 & 1.47 & 1.25 & 0.50 & 1.13 & 1.07 & 0.58 & 1.64 & 1.51 \\
\hline
\end{tabular}




\begin{tabular}{|c|c|c|c|c|c|c|c|c|c|c|c|c|c|}
\hline \multirow[t]{3}{*}{3.} & Mean & 3.88 & 3.49 & 2.41 & 2.89 & 3.30 & 3.20 & 4.50 & 3.14 & 3.14 & 1.67 & 3.21 & 3.25 \\
\hline & Mode & 4 & 4 & 3 & 1 & 3 & 3 & 6 & 2 & 3 & 1 & 3 & 4 \\
\hline & standard dev. & 1.33 & 1.23 & 1.18 & 1.52 & 1.22 & 0.94 & 2.38 & 1.21 & 1.07 & 1.15 & 1.56 & 1.04 \\
\hline \multirow[t]{3}{*}{$4^{*}$} & Mean & 2.99 & 2.98 & 3.29 & 3.11 & 3.85 & 3.07 & 4.25 & 4.57 & 2.43 & 3.00 & 4.02 & 3,38 \\
\hline & Mode & 2 & 2 & 1 & 2 & 6 & 2 & 4 & 5 & 3 & 2 & 5 & 5 \\
\hline & standard dev. & 1.54 & 1.72 & 1.99 & 1.48 & 1.46 & 1.16 & 0.5 & 1.51 & 1.13 & 1.73 & 1.55 & 1.77 \\
\hline \multirow[t]{3}{*}{$5^{\star}}$. & Mean & 3.81 & 3.98 & 4.59 & 4.15 & 3.60 & 4.27 & 3.50 & 4.14 & 3.71 & 5.00 & 4.66 & 5.25 \\
\hline & Mode & 4 & 4 & 6 & 6 & 5 & 5 & 2 & 6 & 5 & 5 & 6 & 6 \\
\hline & standard dev. & 1.75 & 1.55 & 1.62 & 1.77 & 1.59 & 1.71 & 1.91 & 2.11 & 1.98 & 0.00 & 1.76 & 1.49 \\
\hline \multirow[t]{3}{*}{6.} & Mean & 3.80 & 3.53 & 1.94 & 3.22 & 3.10 & 4.13 & 2.50 & 3.43 & 2.43 & 3.67 & 2.27 & 2.13 \\
\hline & Mode & 4 & 5 & 2 & 1 & 4 & 5 & 2 & 3 & 2 & 4 & 2 & 1 \\
\hline & standard dev. & 1.37 & 1.39 & 0.97 & 1.91 & 1.62 & 1.36 & 1.00 & 1.72 & 1.72 & 0.58 & 1.41 & 1.13 \\
\hline \multirow[t]{3}{*}{7.} & Mean & 3.60 & 3.54 & 3.47 & 2.81 & 3.30 & 3.53 & 4.25 & 3.57 & 3.00 & 3.33 & 3.74 & 2.88 \\
\hline & Mode & 3 & 3 & 3 & 3 & 2 & 3 & 5 & 5 & 3 & 4 & 3 & 2 \\
\hline & standard dev. & 1.09 & 1.27 & 1.28 & 1.44 & 1.45 & 1.13 & 0.96 & 1.62 & 1.29 & 1.15 & 1.49 & 1.36 \\
\hline \multirow[t]{3}{*}{8.} & Mean & 3.90 & 3.82 & 2.65 & 2.74 & 3.00 & 3.67 & 3.5 & 3.14 & 4.29 & 4.67 & 2.24 & 2.13 \\
\hline & Mode & 4 & 4 & 1 & 3 & 4 & 4 & 4 & 2 & 3 & 5 & 2 & 3 \\
\hline & standard dev. & 1.16 & 0.91 & 1.65 & 1.26 & 1.17 & 0.62 & 1.29 & 1.86 & 1.38 & 0.58 & 1.49 & 0.99 \\
\hline
\end{tabular}

The central measures (mean and mode) were applied, however, we believed that median is a useless in calculations dealing with a 6 -point scale and a great variety of opinions, as in all cases it would be 2.5 or 3 . And we can rely on a good/desirable result if both the mean and the mode are good.

The items with an asterisk $\left(^{*}\right)$ are the ones with negative items, for them a "good" mean result is equal or less than 3 and the good modes (most often given answers) are 1 or 2 . The other items are positive, for them the good result is equal or above 4 and the good modes are 4, 5 or 6 . Standard deviation higher than 1 reflects heterogeneous opinions within the group. This concerns the next table results, too. 
We can see that the Georgian school teachers in the research view their colleagues' technical skills as moderately good (item 2: mode and mean equal 4 - "more or less agree"). Interestingly, they assess teachers' technical skills (mean $=4.00$, mode $=4$ ) higher than students' ones (mean=3.80, mode=4). Assessments of other items are not positive, rather hesitant (mean between 3.5 and 3.9). The introduction of distance learning was tolerably stressful for them (item 4: mean=2.99 and mode=2 - they "disagree" with its stressfulness. The university teachers did not give any positive answers, while the introduction of distance learning, like for the school teachers, was tolerably stressful for them (item 4: mean=2.98 and mode=2 - they "disagree" with its stressfulness). Interestingly, they assess teachers' technical skills (mean=3.42) lower than students' ones (mean=3.53) or vice versa, compared to the school teachers, but both of them below the desirable level. Standard deviations are high for all items except for the university teachers' assessment of the last item - that they doubt the success of introduction of distance learning. Both the school (mean=3.90) and the university teachers (mean=3.82) express doubts whether the introduction of distance learning in Georgia was successful.

The Iraqi teachers (both school and university) quite negatively assess the readiness for distance learning in their country, more negatively than the respondents from the rest of the countries. However, the Iraqi university teachers and in the majority of items the school teachers are not unanimous in their views (only in items 2 and 6, they are relatively unanimous). They more or less agree that not all their teachers (4.35) or students (4.59) have quality internet. They disagree that their teachers (1.82) or students (1.94) have the necessary technical skills to carry out distance learning. As for the Iraqi university teachers, they more or less agree that not all their teachers (4.07) or students (4.15) have quality internet. Concerning the degree of stressfulness both the school (3.29) and university teachers (3.11) are not sure whether it was stressful. While they hesitate about students' (3.22) technical skills needed for distance learning, they assess teachers' technical skills as low (2.59). Both the school (2.65) and university teachers (2.74) disagree that the introduction of distance learning in Iraq was successful.

The opinions of the Azerbaijani school teachers on all items are heterogeneous (st. dev. $>1$ ), while those of the university teachers are relatively unanimous (in items 1, 3, and 8 the standard deviation is below 1). None of them assess the ongoing processes too positively (the positive items' means are below 4 and the negative items - above 3. Azeri teachers, both the school (3.85) and the university teachers (3.07) hesitate whether the transition to distance learning was stressful for them, however, the school teachers are more inclined to think so. Surprisingly, more university teachers (4.27) think that their students do not have decent internet for studies, while the school teachers (3.60) hesitate on the issue. The Azerbaijani school teachers (3.10) hesitate whether their schoolchildren have the technical skills relevant for distance learning, while the university teachers (4.13) more or less believe that they have them.

The views of the Ukrainian school teachers are often unanimous (on items 1, 3, 4, and 7 the standard deviation is below 1). The majority of the Ukrainian school teachers were rather sincerely enthusiastic (mean $=4.50$ - agree, mode $=6$ - completely agree) about the introduction of compulsory distance teaching. Probably, the degree of preliminary practical experience played its role in this attitude. However, it was more stressful for them (mean=4.25) than for the teachers from the rest of the countries in the study. And they express certain doubts (mean=3.50) concerning the quality of the internet their students have. However, they believe (mean=4.25 - agree, mode=5) that their students were enthusiastic about the introduction of distance learning (probably, as in publications' review is mentioned, they perceived it as additional vacations). Both the school (mean $=4.00$, mode $=4$ ) and the university teachers (mean $=4.43$, mode $=6$ ) admit that their internet facilities are not good enough. Compared to the school teachers (mean=4.50, mode $=6$ ), the university teachers (mean=3.14, mode $=2$ ) had certain doubts concerning the enthusiasm of distance learning introduction. The university teachers also agree that they were stressed by the introduction of distance learning (mean=4.57, mode=5), and they have even stronger doubts (mean=3.14, mode=2) than the school teachers 
(mean=3.5, mode $=4$ ) that the introduction of distance learning has been successful. The Ukrainian university teachers are not unanimous in their answers at all (standard deviations for all items are above 1).

Not surprisingly for the UK as the most developed country in this study, the majority of the school teachers disagree that their colleague do not have a high enough quality of the internet (mean=2.86, mode=2), while the university teachers have a hesitant attitude on the issue (mean $=3.00$, mode $=2$ ). However, the school teachers' opinion of their colleagues' technical skills is only approaching positive $(\operatorname{mean}=3.86$, mode $=4)$, while the university teachers one is hesitant $(\operatorname{mean}=3.67$, mode $=4$; they are quite unanimous is hesitation - st.dev. $=058$ ). Therefore, it is natural that the school teachers were not too enthusiastic about the total introduction of distance learning (mean=3.14, mode=3), while the university teachers were not enthusiastic at all (mean=1.67, mode=1). The school teacher stress level is lower than in all involved in the research countries, but it exists $($ mean $=2.43$, mode $=3$ ), while the university teachers hesitate about having stress (mean=3.0, mode=2). Surprisingly, the school teachers hesitate whether all their students have the necessary quality of the internet (mean=3.71, mode $=5$ ), while the university teachers unanimously agree they have $(m e a n=5.00$, mean $=5)$. More than that, the school teachers' assessment of their students' technical skills is low, the lowest of all countries (mean=2.42, mode $=2$ ), while the university teachers hesitate about their students' technical skills (mean=3.67, mode=4). Either the school teachers from the UK are the strictest among the respondents or they expect some higher-level technical skills from students than teachers from the other countries. However, the school teachers positively enough assess the introduction of total distance learning in the country (mean=4.29, but the mode is 3 ), while the university teachers quite unanimously assess the process positively (mean-4.67, mode $=$, st.dev. $=0.58$ ). While the UK school teachers disagreed a lot with one another's opinions a lot (all standard deviations are above1), the university teachers were relatively unanimous.

The Nigerian school teachers state that not all teachers (mean=4.24, mode $=5)$ and students $(\operatorname{mean}=4.66$, mode $=6)$ have high quality internet. The university teachers also think so (teachers: mean $=4.25$, mode $=4$; students: $\operatorname{mean}=5.25$, mode $=6$ ). The school teachers rather agree that introduction of distance learning was stressful for them (mean=4.02, mode $=5$ ), while the university teachers doubt it was stressful (mean=3.38, mode=5). Both the school (mean=2.24, mode=2) and the university ( $m e a n=2.13$, mode $=3$ ) teachers do not believe that distance learning has been successfully introduced in their country. While the school teachers' answers are heterogeneous (st.dev. is more than 1), the university teachers' views are relatively homogeneous (st.dev. of some items is below 1 ).

Table 4. Teachers' results according to age groups: Georgia, Iraq, Azerbaijan and Ukraine

\begin{tabular}{|c|c|c|c|c|c|c|c|c|c|c|c|c|c|c|c|c|c|c|c|}
\hline \multirow[t]{2}{*}{ nt./ } & \multirow{2}{*}{$\begin{array}{l}\text { Dat } \\
\text { a } \\
\text { Age }\end{array}$} & \multicolumn{3}{|c|}{ Georgia } & \multicolumn{3}{|c|}{ Iraq } & \multicolumn{3}{|c|}{ Azerbaijan } & \multicolumn{3}{|c|}{ Ukraine } & \multicolumn{3}{|c|}{ Nigeria } & \multicolumn{3}{|l|}{ UK } \\
\hline & & $\begin{array}{l}<3 \\
0\end{array}$ & $\begin{array}{l}31 \\
- \\
50\end{array}$ & $\begin{array}{l}>5 \\
0\end{array}$ & $\begin{array}{l}<3 \\
0\end{array}$ & $\begin{array}{l}31 \\
- \\
50\end{array}$ & $\begin{array}{l}>5 \\
0\end{array}$ & $\begin{array}{l}<3 \\
0\end{array}$ & $\begin{array}{l}31 \\
- \\
50\end{array}$ & $\begin{array}{l}>5 \\
0\end{array}$ & $\begin{array}{l}<3 \\
0\end{array}$ & $\begin{array}{l}31 \\
- \\
50\end{array}$ & $\begin{array}{l}>5 \\
0\end{array}$ & $\begin{array}{l}<3 \\
0\end{array}$ & $\begin{array}{l}31 \\
- \\
50\end{array}$ & $\begin{array}{l}>5 \\
0\end{array}$ & $\begin{array}{l}<3 \\
0\end{array}$ & $\begin{array}{l}31 \\
- \\
50\end{array}$ & $\begin{array}{l}>5 \\
0\end{array}$ \\
\hline $1^{*}$ & $\begin{array}{l}\text { mea } \\
\mathrm{n}\end{array}$ & $\begin{array}{l}3.0 \\
4\end{array}$ & $\begin{array}{l}3.8 \\
5\end{array}$ & $\begin{array}{l}4.1 \\
5\end{array}$ & $\begin{array}{l}3.8 \\
0\end{array}$ & $\begin{array}{l}4.8 \\
1\end{array}$ & $\begin{array}{l}3.5 \\
5\end{array}$ & $\begin{array}{l}4.2 \\
0\end{array}$ & $\begin{array}{l}3.6 \\
9\end{array}$ & $\begin{array}{l}3.4 \\
5\end{array}$ & $\begin{array}{l}3.3 \\
3\end{array}$ & $\begin{array}{l}4.1 \\
4\end{array}$ & $\begin{array}{l}4.8 \\
3\end{array}$ & $\begin{array}{l}3.9 \\
3\end{array}$ & $\begin{array}{l}4.5 \\
0\end{array}$ & $\begin{array}{l}5.1 \\
3\end{array}$ & n.a & 1.6 & $\begin{array}{l}3.8 \\
0\end{array}$ \\
\hline
\end{tabular}




\begin{tabular}{|c|c|c|c|c|c|c|c|c|c|c|c|c|c|c|c|c|c|c|c|}
\hline & $\begin{array}{l}\text { mo } \\
\text { de }\end{array}$ & 2 & 5 & 5 & $\begin{array}{l}2 \\
\text { an } \\
\text { d } 5\end{array}$ & 6 & 4 & 5 & 5 & 4 & 4 & $\begin{array}{l}4 \\
\text { an } \\
\text { d } 6\end{array}$ & $\begin{array}{l}5 \\
\text { an } \\
\text { d } 6\end{array}$ & 3 & 5 & 5 & n.a & 2 & 5 \\
\hline & $\begin{array}{l}\text { st. } \\
\text { dev. }\end{array}$ & $\begin{array}{l}1.3 \\
9\end{array}$ & $\begin{array}{l}1.5 \\
0\end{array}$ & $\begin{array}{l}1.3 \\
7\end{array}$ & $\begin{array}{l}1.8 \\
7\end{array}$ & $\begin{array}{l}1.1 \\
5\end{array}$ & $\begin{array}{l}1.4 \\
4\end{array}$ & $\begin{array}{l}1.2 \\
3\end{array}$ & $\begin{array}{l}1.4 \\
9\end{array}$ & $\begin{array}{l}1.2 \\
9\end{array}$ & $\begin{array}{l}0.8 \\
2\end{array}$ & $\begin{array}{l}1.7 \\
7\end{array}$ & $\begin{array}{l}1.1 \\
6\end{array}$ & $\begin{array}{l}1.7 \\
7\end{array}$ & $\begin{array}{l}1.6 \\
0\end{array}$ & $\begin{array}{l}0.5 \\
2\end{array}$ & $\begin{array}{l}\text { n.a } \\
.\end{array}$ & $\begin{array}{l}0.5 \\
5\end{array}$ & $\begin{array}{l}1.3 \\
0\end{array}$ \\
\hline \multirow[t]{3}{*}{2.} & $\begin{array}{l}\text { mea } \\
\mathrm{n}\end{array}$ & $\begin{array}{l}4.0 \\
4\end{array}$ & $\begin{array}{l}3.6 \\
3\end{array}$ & $\begin{array}{l}3.5 \\
1\end{array}$ & $\begin{array}{l}2.8 \\
0\end{array}$ & $\begin{array}{l}2.3 \\
5\end{array}$ & $\begin{array}{l}2.4 \\
5\end{array}$ & $\begin{array}{l}3.8 \\
0\end{array}$ & $\begin{array}{l}3.3 \\
8\end{array}$ & $\begin{array}{l}3.1 \\
8\end{array}$ & $\begin{array}{l}4.1 \\
7\end{array}$ & $\begin{array}{l}2.4 \\
3\end{array}$ & $\begin{array}{l}3.1 \\
7\end{array}$ & 3.5 & $\begin{array}{l}2.9 \\
8\end{array}$ & $\begin{array}{l}2.0 \\
0\end{array}$ & n.a & $\begin{array}{l}4.0 \\
0\end{array}$ & $\begin{array}{l}2.2 \\
0\end{array}$ \\
\hline & $\begin{array}{l}\text { mo } \\
\text { de }\end{array}$ & 4 & 4 & 4 & 2 & 1 & 2 & 4 & 2 & 3 & 5 & 2 & 3 & $\begin{array}{l}3 \\
\text { an } \\
\text { d } 6\end{array}$ & 1 & 2 & n.a & 4 & 2 \\
\hline & $\begin{array}{l}\text { st. } \\
\text { dev. }\end{array}$ & $\begin{array}{l}1.5 \\
7\end{array}$ & $\begin{array}{l}1.4 \\
7\end{array}$ & $\begin{array}{l}1.3 \\
0\end{array}$ & $\begin{array}{l}1.4 \\
8\end{array}$ & $\begin{array}{l}1.3 \\
2\end{array}$ & $\begin{array}{l}0.9 \\
3\end{array}$ & $\begin{array}{l}1.6 \\
2\end{array}$ & $\begin{array}{l}1.3 \\
9\end{array}$ & $\begin{array}{l}1.0 \\
8\end{array}$ & $\begin{array}{l}1.4 \\
8\end{array}$ & $\begin{array}{l}0.7 \\
9\end{array}$ & $\begin{array}{l}0.7 \\
5\end{array}$ & $\begin{array}{l}1.9 \\
1\end{array}$ & $\begin{array}{l}1.6 \\
4\end{array}$ & $\begin{array}{l}0.8 \\
5\end{array}$ & n.a & $\begin{array}{l}0.7 \\
1\end{array}$ & $\begin{array}{l}1.1 \\
0\end{array}$ \\
\hline \multirow[t]{3}{*}{3.} & $\begin{array}{l}\text { mea } \\
\mathrm{n}\end{array}$ & $\begin{array}{l}3,7 \\
6\end{array}$ & $\begin{array}{l}3.7 \\
5\end{array}$ & $\begin{array}{l}4.0 \\
7\end{array}$ & $\begin{array}{l}3.0 \\
0\end{array}$ & $\begin{array}{l}2.7 \\
7\end{array}$ & $\begin{array}{l}2.0 \\
0\end{array}$ & $\begin{array}{l}2.8 \\
0\end{array}$ & $\begin{array}{l}2.7 \\
7\end{array}$ & $\begin{array}{l}3.8 \\
1\end{array}$ & $\begin{array}{l}4.0 \\
0\end{array}$ & $\begin{array}{l}3.2 \\
9\end{array}$ & $\begin{array}{l}4.0 \\
0\end{array}$ & $\begin{array}{l}3.1 \\
4\end{array}$ & $\begin{array}{l}3.0 \\
0\end{array}$ & $\begin{array}{l}3.2 \\
0\end{array}$ & n.a & $\begin{array}{l}2.4 \\
0\end{array}$ & $\begin{array}{l}2.6 \\
0\end{array}$ \\
\hline & $\begin{array}{l}\text { mo } \\
\text { de }\end{array}$ & 3 & 4 & 4 & 3 & $\begin{array}{l}1 \\
\text { an } \\
\text { d } 3\end{array}$ & 1 & 3 & 3 & 3 & 5 & 2 & 4 & 2 & 2 & 1 & n.a & 3 & 3 \\
\hline & $\begin{array}{l}\text { st. } \\
\text { dev. }\end{array}$ & $\begin{array}{l}1.5 \\
6\end{array}$ & $\begin{array}{l}1.3 \\
5\end{array}$ & $\begin{array}{l}1.4 \\
2\end{array}$ & $\begin{array}{l}1.2 \\
5\end{array}$ & $\begin{array}{l}1.4 \\
2\end{array}$ & $\begin{array}{l}1.2 \\
6\end{array}$ & $\begin{array}{l}1.3 \\
2\end{array}$ & $\begin{array}{l}1.0 \\
9\end{array}$ & $\begin{array}{l}0.9 \\
8\end{array}$ & $\begin{array}{l}0.6 \\
2\end{array}$ & $\begin{array}{l}2.0 \\
0\end{array}$ & $\begin{array}{l}1.4 \\
1\end{array}$ & $\begin{array}{l}1.5 \\
1\end{array}$ & $\begin{array}{l}1.4 \\
6\end{array}$ & $\begin{array}{l}1.9 \\
3\end{array}$ & n.a & $\begin{array}{l}0,7 \\
9\end{array}$ & $\begin{array}{l}1.1 \\
4\end{array}$ \\
\hline \multirow[t]{3}{*}{$4^{*}$} & $\begin{array}{l}\text { mea } \\
\mathrm{n}\end{array}$ & $\begin{array}{l}3,1 \\
2\end{array}$ & $\begin{array}{l}3.4 \\
6\end{array}$ & $\begin{array}{l}3.0 \\
8\end{array}$ & $\begin{array}{l}3.0 \\
0\end{array}$ & $\begin{array}{l}3.4 \\
6\end{array}$ & $\begin{array}{l}3.1 \\
8\end{array}$ & $\begin{array}{l}4.0 \\
0\end{array}$ & $\begin{array}{l}3.3 \\
1\end{array}$ & $\begin{array}{l}3.4 \\
5\end{array}$ & $\begin{array}{l}4.0 \\
0\end{array}$ & $\begin{array}{l}4.4 \\
2\end{array}$ & $\begin{array}{l}5.0 \\
0\end{array}$ & $\begin{array}{l}5.0 \\
0\end{array}$ & $\begin{array}{l}4.0 \\
0\end{array}$ & $\begin{array}{l}4.2 \\
7\end{array}$ & n.a & $\begin{array}{l}2.4 \\
0\end{array}$ & $\begin{array}{l}3.0 \\
0\end{array}$ \\
\hline & $\begin{array}{l}\text { mo } \\
\text { de }\end{array}$ & 4 & 2 & 2 & 1 & $\begin{array}{l}2 \\
\text { an } \\
\text { d } 5\end{array}$ & $\begin{array}{c}2 \\
\text { an } \\
\text { d } 4\end{array}$ & 5 & 5 & 2 & 4 & 5 & 6 & 6 & 5 & 5 & n.a & 2 & 3 \\
\hline & $\begin{array}{l}\text { st. } \\
\text { dev. }\end{array}$ & $\begin{array}{l}1.5 \\
1\end{array}$ & $\begin{array}{l}1.8 \\
4\end{array}$ & $\begin{array}{l}1.6 \\
3\end{array}$ & $\begin{array}{l}1.9 \\
0\end{array}$ & $\begin{array}{l}1.6 \\
5\end{array}$ & $\begin{array}{l}1.0 \\
7\end{array}$ & $\begin{array}{l}1.4 \\
9\end{array}$ & $\begin{array}{l}1.1 \\
8\end{array}$ & $\begin{array}{l}1.4 \\
4\end{array}$ & $\begin{array}{l}1.4 \\
1\end{array}$ & $\begin{array}{l}1.2 \\
7\end{array}$ & $\begin{array}{l}1.2 \\
6\end{array}$ & $\begin{array}{l}1.3 \\
0\end{array}$ & $\begin{array}{l}1.5 \\
8\end{array}$ & $\begin{array}{l}0.8 \\
0\end{array}$ & n.a & $\begin{array}{l}1.5 \\
2\end{array}$ & $\begin{array}{l}0.7 \\
1\end{array}$ \\
\hline \multirow[t]{2}{*}{$5^{*}}$. & $\begin{array}{l}\text { mea } \\
\mathrm{n}\end{array}$ & $\begin{array}{l}3.8 \\
8\end{array}$ & $\begin{array}{l}3.8 \\
1\end{array}$ & $\begin{array}{l}3.7 \\
4\end{array}$ & $\begin{array}{l}3.9 \\
0\end{array}$ & $\begin{array}{l}4.9 \\
2\end{array}$ & $\begin{array}{l}4.5 \\
4\end{array}$ & $\begin{array}{l}4.1 \\
0\end{array}$ & $\begin{array}{l}4.2 \\
3\end{array}$ & $\begin{array}{l}3.4 \\
5\end{array}$ & $\begin{array}{l}2.1 \\
7\end{array}$ & $\begin{array}{l}4.2 \\
9\end{array}$ & $\begin{array}{l}2.6 \\
7\end{array}$ & $\begin{array}{l}4.5 \\
7\end{array}$ & $\begin{array}{l}4.3 \\
5\end{array}$ & $\begin{array}{l}5.6 \\
0\end{array}$ & n.a & 3.2 & $\begin{array}{l}5.2 \\
0\end{array}$ \\
\hline & $\begin{array}{l}\text { mo } \\
\text { de }\end{array}$ & 4 & 4 & 5 & 6 & 6 & 5 & 6 & 6 & 4 & 2 & 6 & 3 & 6 & 5 & 6 & n.a & 5 & 5 \\
\hline
\end{tabular}




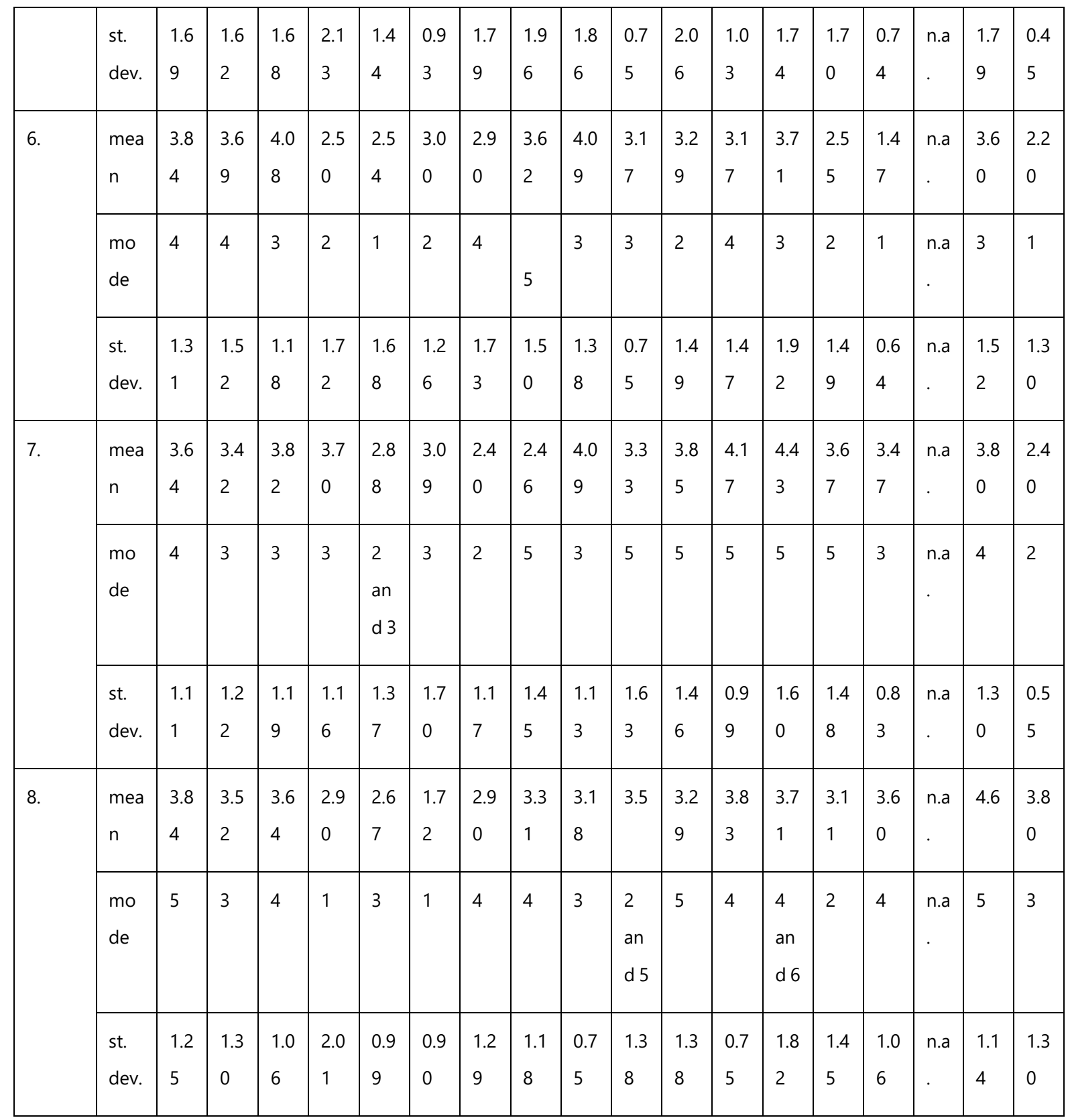

The opinions of the Georgian teachers on readiness to sudden total distance learning do not much depend, as it is generally expected, on their age. On the quality of the internet that teaches possess the teachers older than 50 are especially negative (mean=4.15, mode=5). Concerning teacher's technical skills the teachers younger than 30 have the most positive opinions (mean=4.04, mode=4). On the other hand, concerning teacher enthusiasm, the teachers older than 50 are especially positive (mean=4.07, mode $=4$ ). Also on students' technical skills the older than 50 years old teachers are especially enthusiastic ( mean $=4.08$, however, the mode $=3$ ). The teachers of all ages hesitate about the success of implementation of distance learning in Georgia (mean=3.84; 3.52 and 3.64).

In Iraq, not all teachers have high enough quality internet, according to teachers aged between 30 and 50 (mean=4.81, mode=6), while younger and older teachers hesitate whether it is so. About the quality of students' internet, the teachers aged 30-50 (mean=4.92, mode $=6)$ and older than $50($ mean=4.54, mode $=5)$ have a low opinion. While the younger teachers very much disagree on the issue (st.dev. $=2.13$ ), the teachers older than 50 quite agree with each other $($ st.dev. $=0.93)$. Concerning students' 
technical skills, the teachers aged till 50 believe that they are low, while the teachers older than 50 hesitate in their opinion. The teachers of all ages quite unanimously (especially the older teachers believe that the implementation of distance learning was not successful (the younger teachers - mean $=2.90$, mode $=1$; the teachrs aged between 30 and 50 - mean=2.67, mode $=3$; those older than $50-$ mean $=1.72$, mode $=1$ ). Therefore, there is a weak trend of the teachers aged older than 50 to assess the situation more negatively.

Among the Azerbaijani teachers, the young teachers are especially critical concerning the quality of teachers' internet facilities (mean=4.20, compared to 3.69 and 3.45, respectively, of older teachers). Unexpectedly, for the young teachers the introduction of distance learning turned out to be more stressful than for the teachers older than 30, probably, due to lack of experience (mean $=4.00$, compared correspondingly to 3.31 and 3.45), which reveals that age (the younger, the better the attitude) does not have the normally expected impact. The teachers younger than 30 (mean=4.10) and aged between 30 and 50 (mean=4.23) believe that the quality of students' internet is not good enough, compared to the teachers older than 50 (mean=3.45), which may be explained by their higher requirements to the internet. Students' technical skills are also assessed higher by the teachers older than 50 (mean=4.09, mode=3), than, consecutively, by the young teachers $(\operatorname{mean}=2.90)$ and the teachers aged between 30 and 50 (mean=3.62). This may be explained the same way. Interestingly, the teachers younger than 30 $($ mean $=2.40$, mode $=2)$ and those aged between 30 and 50 (mean=2.46, mode=5) assess student enthusiasm negatively, and much lower than teachers aged above 50 (mean=4.09, mode=3). The young teachers' view on success of distance learning introduction in Azerbaijan is negative (mean $=2.90$, mode $=4)$, while the teachers aged between 30 and $50(\operatorname{mean}=3.31$, mode $=4)$ and older than 50 (mean=3.18, mode=3) doubt about its success. On the whole, unexpectedly, the young teachers assess the readiness for distance learning on a lower level than their older colleagues.

On 4 items the Ukrainian young teachers are rather unanimous in their opinion (st.dev. is less than 1). There are three items where the teachers older than 50 agree with each other more or less unanimously (st.dev. is below 1), while the teachers aged between 30 and 50 have quite heterogeneous opinions. While the young teachers (mean=3.33, mode $=4$ ) hesitate concerning their colleagues' internet quality, the teachers aged between 30 and 50 (mean=4.14; mode ${ }_{1}=4$ and mode $\left.=6\right)$ and older than $50\left(\right.$ mean $=4.4 .83$, mode $_{1}=5$ and mode $\left._{2}=6\right)$ do not think it is of high quality. Concerning teachers' technical skills, the young teachers believe they are of high quality (mean=4.17, mode=5), the teachers aged between 30 and 50 think it is not so $($ mean $=2.43$, mode $=2)$, and the teachers older than 50 hesitate $(\operatorname{mean}=3.17$, mode $=3)$. While the younger teachers $($ mean $=4.00$, mode $=5)$ and the teachers older than $50($ mean $=4.00$, mode $=4)$ believe that teachers were quite enthusiastic concerning the introduction of distance learning, the teachers aged between 30 and 50 hesitate about it (mean=3.29, mode=2). The teachers of all ages admitted they were stressed, however, the older they are, the higher stress (consecutively, mean $_{1}=4.00$, mode $_{1}=4$; mean $_{2}=4.43$, mode $_{2}=5 ;$ mean $_{3}=5.00$, mode $_{3}=3$ ) they admitted. The quality of students' internet is also assessed in a contradictory way: the younger teachers (mean $=2.17$, mode $=2$ ) and the teachers older than 50 (mean=2.67, mode-3) think it is low, while the teachers aged between 30 and 50 hesitate (mean $=4.29$, mode $=6$ ).

Concerning teachers' internet quality, the Nigerian teachers' views decrease with age: the young teachers' view is hesitant, approaching negative ( mean $=3.93$, mode $=3$ ), the teachers aged between 30 and 50 is negative $(\operatorname{mean}=4.50$, mode $=5$ ), while the teachers' older than 50 view is very negative and quite homogeneous (mean $=5.13$, mode-5, st.dev. $=0.52$ ). Concerning teacher technical skills, the trend is the same: the more the teachers' age, the lower their assessment of teachers' technical skills, the teachers' who are older than 50 opinion being quite homogeneous (consecutively, mean $1=3.50$, mode $_{1}=3$ and $6 ;$ mean $_{2}=2.98$, mode $_{2}=1 ;$ mean $_{3}=2.00$, mode $_{3}=2$, st.dev. $\left.=0.85\right)$. While, surprisingly, the youngest teachers admit the strongest stress $($ mean $=5.00$, mode $=6$ ), the teachers aged between 30 and 50 have the lowest (but still existing) stress ( $m e a n=4.00$, mode $=5$ ), and the teachers older than 50 have a relatively high stress, with quite a unanimous view on it (mean $=4.27$, mode $=5$ st.dev. $=0.80$ ). Concerning the 
level of students' technical skills, the young teachers are hesitating (mean=3.71, mode=3), the teachers aged between 30 and 50 view them as low (mean=2.55, mode $=2$ ), while the teachers older than 50 quite unanimously (st.dev. $=0.44$ ) believe they are quite low-level (mean=1.47, mode=1. Concerning students' enthusiasm in connection with the introduction of distance learning, the young teachers assess it positively $\left(\right.$ mean $_{1}=4.43$, mode $\left.1=5\right)$, while older teachers hesitate $($ mean $=3.67$, mode $=5$; and mean $=3.47$, mode=3). Here we can speak about the dependence of opinions on the age of the respondents. The teachers of all three age groups hesitate concerning the success of the introduction of distance learning. Compared to other countries, the answers to several items of teachers from Nigeria follow the principle 'the younger the teacher, the more positive the opinion.'

The UK respondents' group is the smallest, so their answers may not be reliable. The majority of the answers are quite heterogeneous, only in three items do they more or less agree with each other (st.dev. is below 1). The teachers younger than 30 have not responded at all. The quality of teacher internet has been assessed as high by the teachers aged between 30 and 50 (mean=1.6, mode=2), while the teachers older than 50 hesitate about its quality (mean=3.0, mode=5). Teacher technical skills were assessed as good (mean=4.2, mode $=6$ ) by the teachers aged between 30 and 50, while the teachers older than 50 assessed them as low-level (mean=2.20, mode=2). Whatever their age, they believe that teacher enthusiasm in connection with the introduction of distance learning is low / hesitant ( mean $_{1}=2.40$, mode $_{1}=3 ; \operatorname{mean}_{2}=2.60, \operatorname{mode}_{2}=3$ ). On the other hand, their stress in connection with distance teaching is perceived as either low (the teachers aged from 30 to 50: mean=2.4, mode=2; those older than 50 mean $=3$, mode $=3$ ). While the teachers aged from 30 to 50 hesitate about the quality of their students' internet $($ mean $=3.2$, mode $=5$ ), the older than 50 teachers quite unanimously think it is low (mean=5.20, mode $=5$, st.dev. $=0.45$ ). Concerning students' technical skills and enthusiasm the teachers of both age groups are hesitant. The teachers aged between 30 and 50 assessed the implementation of distance learning as positive (mean=4.6, mode=5), while the older teachers hesitate about it $($ mean $=3.0$, mode $=3$ ).

As for the respondents from the other countries, they cannot be statistically treated, but they reveal similar trends.

On the whole it should be mentioned that both according to countries and age groups there are certain differences in assessment of the readiness to distance learning, however, there is no clear-cut age dependence on the views.

\subsection{Discussion}

Depending on the country and a particular school / university, different degrees of readiness may be found. Besides, personal and cultural peculiarities of the respondents matter in defining the balance of positive/negative assessment of distance learning, which puts their objectivity under certain doubt.

There are quite few publications in the years preceding the COVID-19 pandemic dedicated to simply measuring / defining the readiness level, the majority of publications compare the degree of readiness between various majors or male and female students (Keskin \& Yurdugül, 2020) or study the impact of readiness on academic achievement (Aldhafeeri \& Khan, 2016). As for the period of the spread of global pandemic, there are practically no researches yet, and we realize that our research is sort of 'raw', but we hope it is needed.

Caliskan, Tugun, and Uzunboylu (2017) studied university students' readiness for e-learning in North Cyprus and found it positive. By 'readiness' they meant computer and internet self-efficacy, online communication and self-learning skills, as well as e-learning motivation. Unfortunately, the article does not reveal whether the participant students were learning completely online or only did part of their studies through internet.

Gay (2016) conducted a study at the Caribbean university (Puerto Rico) with four campuses, one of which offers courses in an online environment. 208 online instructors from across 17 Caribbean countries filled in questionnaires dealing with their 
technical, lifestyle and pedagogical readiness. The study revealed that, while $90.6 \%$ were technologically ready, only $72.6 \%$ were ready pedagogically and from the lifestyle viewpoint.

Ngampornchai and Adams (2016) study was held in Thailand. The survey explored students' readiness in terms of selfregulation, computing devices ownership, and level of familiarity with education-related technologies. The responses implied that students had a slightly positive perception of e-learning.

Compared to the existing studies, this research revealed a lower degree of readiness to study online. This difference can be ascribed to two major causes:

1) in the cited studies going online was voluntary;

2) in the cited studies (except Gay, 2016) going online was only partial and the model of education was mixed - onsite and online, which, undoubtedly, is effective and desirable.

\subsection{Limitations}

The limitations of the research deal with the number of participants, which need to be much higher. But, in order to timely start better teacher and student preparation for distance education, to make the reaction to evolving situations faster and more effective, we believed that such a blitz research is useful, at least thought-provoking. As the questionnaire is provided in the article, the research is replicable, so the authors will be glad if it is continued on a larger scale.

\section{Conclusions}

As the existing publications reveal, the shifting to e-learning in the described countries followed more or less the same pattern: some e-learning materials and experience existed beforehand, however, often insufficient. It occurred more or less suddenly, which caused certain delays in providing requirements, recommendations and conditions, however, on the whole international organizations, IT companies, and Ministries of Education contributed a lot. But, of course, the legislation and university regulations have to be developed to enable making completely switching to e-learning legal (at least, in certain conditions) and organized. More e-learning materials need to be developed in languages other than English, especially in languages of ethnic minorities. Teacher e-skills (both technical and pedagogical) have to be improved and diversified. They need to be more efficiently motivated to use e-teaching. Student autonomy has to be developed.

The results of the research have shown (many teachers expressed this opinion in in the comments to the questionnaire) that, even if we are not well enough prepared for distance learning, it is inevitable (hopefully, as a temporary alternative to faceto-face education), and that it can be done by all teachers. Many teachers had to learn it in extreme conditions, however, everybody mastered it, although the quality of the provided by them teaching was not always relevant.

Among the countries, the highest level of readiness was revealed by the UK teachers. The university teachers answered they were to a certain degree more prepared for the shift. As for the teachers' age, higher readiness / assessment by younger teachers was not discovered.

And in the future we need to think about further developing teachers' technical and pedagogical skills of e-teaching, in order to increase the quality of education, use up-to-date teaching methods and be ready for unexpected situations when we may need to move to it totally. 


\section{Acknowledgements}

The authors express their warmest gratitude to all respondents, and special thanks to Agnes Dada-Fatogun, lan Gadd, Georgios Dafoulas, Giorgi Nozadze Maya Abdelani, Iryna Fedorchuk, Natalia Hromova, Neli Meraabishvili, Nino Kirvalidze, Oyinkansola Somorin, Paul Esupofo Oriade, Paul Hyland, Suleyman Chelik, Tamuna Khetaguri, and Venera Ulker, for helping to collect more responses.

\section{Contributors}

The following pieces of the article have been provided by the mentioned authors: Georgia (Natela Doghonadze), Ukraine (Ludmila Knodel), The UK and Nigeria (Adebayo Samuel Adedoyin), Iraq (Huda Halawachy) and Azerbaijan (Aydin Aliyev) 


\section{References:}

Agenda.ge. (2020, March 11). Some of Georgian universities switching to remote classes, service for coronavirus prevention. Retrieved April 4, 2020 from https://agenda.ge/en/news/2020/757

Ajadi, T.O., Olatunde, S.I., \& Adeoye, F. A. (2008). E-learning and distance education in Nigeria. Turkish Online Journal of Educational Technology, 7(4). Retrieved 4 22, 2020, from https://files.eric.ed.gov/fulltext/ED503472.pdf

Aldhafeeri, F. \& Khan, B. (2016). Teachers' and students' views on e-learning readiness in Kuwait's secondary public schools. Journal of Educational Technology Systems, 45 (2), 202-235. https://doi.org/10.1177/0047239516646747

Aliyeva, T., \& Rzayeva, U. (2019). E-education as a new education paradigm: Case of Azerbaijan. IEEE 13th International Conference on Application of Information and Communication Technologies (AICT), (pp. 1-5). Baku.

Al-Juboori, T. (2020). The Strategy of E-learning in Iraqi Higher Education: Ambition and Challenging. Al-Bayan Center for Planning and Studies. Retrieved April 5, 2020 from http://www.bayancenter.org/2020/04/5786/

Al-Mayaali, F. \& Al-Hijamami, T. (2009). The Nature of Learning and the Problems Facing Distance Learning in Iraq. College of Education for Humanity Sciences (for Women), 5, 1-23.

Al-Qazaaz, A. (2014). E-learning and its mountain trip in Iraq. Journal of Al-Turath University College, 14, 68-92.

Annetta, L. (2004). Investigating the relationship between cost, reach, and richness in distance education. Online Journal of Distance Learning Administration, 7, 4. Retrieved April 1, 2020 from https://eric.ed.gov/?id=EJ1114187

BBC. (2020, 23.03). Coronavirus: Parents heed calls not to send children to school. Retrieved April 19, 2020 from https://www.bbc.com/news/education-51999539

BBC. (2020, 18.03). BBC sets out plan to inform, educate and entertain during unprecedented times. Retrieved April 18, 2020, from BBC Media Centre: https://www.bbc.co.uk/mediacentre/latestnews/2020/bbc-keeping-nation-informed-educatedentertained

Boudreau, E. (2020, April 3). Toward a Global Response to COVID-19. Harvard Graduate School of Education. Retrieved April 24, 2020 from https://www.gse.harvard.edu/news/uk/20/04/toward-global-response-covid-19

Bozkurt, A. (2019). From distance education to open and distance learning: A holistic evaluation of history, definitions, and theories. In S.Sisman-Ugur, \& G. Kurubacak (Eds.). Handbook of Research on Learning in the Age of Transhumanism (pp. 252-273). Hershey, PA: IGI Global.

British Council. (n.d). Covid-19 Learning Support. Retrieved April 18, 2020, from Learn English British Council: https://learnenglish.britishcouncil.org/covid-19-learning-support

British Council Azerbaijan. (2020, April 13). \#StayHome with the British Council. Retrieved 25 April 2020 from https://www.britishcouncil.az/en/stay-home

Busby, E. (2020). Coronavirus: UK schools prepare for online classes in event of widespread closures. Independent, 04.03. Retrieved April 19 from https://www.independent.co.uk/news/education/education-news/coronavirus-school-closures-onlineclasses-teachers-pupils-uk-a9376181.html

Caliskan, S., Tugun, V. \& Uzunboylu, H. (2017). University students' readiness for E-Learning. ENSAYOS, Revista de la Facultad de Educación de Albacete, 32(2). Retrieved April 20, 2020 from http://dialnet.uniroja.es/discarga'articulo/6535827.pdf 
Colleges and Degrees. (2020). Understanding Accreditation. Retrieved April 1, 2020 from https://www.collegesanddegrees.com/accreditation

CommonWealth of Learning. (2020, 4 16). Keeping the Doors of Learning Open. COVID-19. Retrieved April 23, 2020, from https://www.col.org/resources/keeping-doors-learning-open-covid-

19?fbclid=IwAROvVGVi5fNKoSYfEKJV8xQsBCHnsiCoz7WoXIpRa7B2i3iSDM2Ezlj9Fk8

Crowther, G. (1969). Speech by Lord Crowther, first Chancellor of The Open University at the presentation of the Charter (Transcript). Open University. Retrieved April 17, 2020, from https://www.open.ac.uk/library/digitalarchive/pdf/script/script:5747089b4a53f

David, F. (2020, 4 6). COVID-19 - Online learning: A Teacher's Perspective. Retrieved April 10, 2020 from Tech UK: https://www.techuk.org/insights/opinions/item/17240-covid-19-online-learning-a-teachers-perspective

Delegation of the European Union to Georgia. (2020). EU announces support package for Georgia. Retrieved April 4, 2020 from eas.europa.eu/delegations/georgia/76721/coronavirus-european-union-stands-togethergeorgia_en?fbclid=IwAR2e8peR7A936ml7I9FhmpiwVhd0pbWTsR3RID-IOk7WC6XF3_TlyS7qUFI

Deparment for Education. (2020, 07.04). Guidance Coronavirus (COVID-19): Closure of educational settings: information for parents and carers. Retrieved April 10, 2020 from Gov.Uk: https://www.gov.uk/government/publications/closure-of-educationalsettings-information-for-parents-and-carers/closure-of-educational-settings-information-for-parents-and-carers

Department for Education. (2020, 17.04). Guidance Coronavirus (COVID-19): Financial Support for Education, Early Years and Children's Social Care. Retrieved April 18, 2020, from Gov.Uk: https://www.gov.uk/government/publications/coronaviruscovid-19-financial-support-for-education-early-years-and-childrens-social-care/coronavirus-covid-19-financialsupport-for-education-early-years-and-childrens-social-care

Dumford, A.D. \& Miller, A.L. (2018). Online learning in higher education: exploring advantages and disadvantages for engagement. Journal of Computing in Higher Education, 30, 452-465.

Economic Confidential. (2020, April 16). COVID-19: When the Open University Remains Open. Retrieved 4 23, 2020, from Economic Confidential: https://economicconfidential.com/2020/04/covid19-open-university-remains-open/

Education and Trainng Foundation. (2020, 03.04). News. Retrieved April 18, 2020, from Education and Trainng Foundation: https://www.et-foundation.co.uk/news/

Education in Emergency Working Group (EiEWG). (2020). Nigeria Education Sector COVID19 Response Strategy in North East. Education in Emergency Working Group (EiEWG). Retrieved April 23, 2020, from https://reliefweb.int/sites/reliefweb.int/files/resources/nigeria_education_sector_covid19_response_strategy_north_east_.pdf

Etaloni.ge (2020, March 26). Gtkhovt, ccotati mainc gagvigit mastsavleblebs, chven shokuri mdgomareoba gvaqvs (In Georgian: Please understand us, teachers, we are shocked). Retrieved April 4, 2020 from https://www.etaloni.ge/geo/main/index/36990?fbclid=IwAR14evGg-8a5vHUhPUWFdQ8QG-Q42XgNXaAPiVy8QLveObaX9KXcfb6E2c

Federal Ministry of Education of Nigeria. (2020). Management of Corona Virus Pandemic. Garki, Abuja: Office of the Permanent Secretary. Retrieved April 23, 2020, from https://drive.google.com/file/d/1fD3k-zjB_NRrOOROedqCQUYAF_MRp92C/view 
Gay, G. (2016). An assessment of online instructor e-learning readiness before, during, and after course delivery. Journal of Computing in Higher Education, 28, 199-220.

Gorgodze, Salome. (2020). Onlain stwavleba - ra gamotswvevebis tsinashe aghmochnda Sistema, skola, mastsavleblebi (In Georgian: Online teaching - In front of what challenges happened to be the system, school, and teachers). Retrieved April 6, 2020 from https://publika.ge/article/onlainswavleba-ra-gamowvevebis-winashe-aghmochnda-sistema-skolamaswavleblebi/?fbclid=IwAR37VWBBqI2koT1-RDKu1zRJUkLI_6fNvqX_ESO8Frq7yAF8FUeoPJShmEY

Gossenheimer, A.N., Bem, T., Carneiro, M.L., \& de Castro, M. (2017). Impact of distance education on academic performance in a pharmaceutical care course. Plos One, 12 (4), e0175117. Retrieved April 1, 2020 from https://journals.plos.org/plosone/article?id=10.1371/journal.pone.0175117

Hafta.az. (2020, April 9). Azerbaycanda təhsil müəssisələri online təhsilə hazır deyil-Problem [Educational institutions in Azerbaijan are not ready for online education-Problem]. Retrieved 25 Apr 2020 from hafta.az: http://hafta.az/azerbaycanda-tehsilmuessiseleri-online-tehsile-hazir-deyil-problem-276800-xeber.html

Halawachy, H. (In preparation). "Not Too googlish!Google Classroom in the Authors' Eyes Accompanying My Pros, Cons, and Sighs!".

Hall, A. (2020, 3 15). COVID-19 Coronavirus - Advice for Schools. Retrieved April 10, 2020 from Safeguarding in Schools: https://www.safeguardinginschools.co.uk/covid-19-coronavirus-advice-for-schools/

Hasan, R. \& Hmood, H. (2009). The basic aspects of transformation from traditional learning to e-learning. Al-Adab Journal, 91, 486-501.

Hromadske International. (2020, April 6). How Ukraine's Education System Adapts to Coronavirus Quarantine. Retrieved April 10, 2020 from https://en.hromadske.ua/posts/how-ukraines-education-system-adapted-during-coronavirus-quarantine

Ikenwa, C. (1999). List of Accredited Universities that Run Distant Learning in Nigeria. Retrieved April 23, 2020, from nigerianinfopedia.com: https://nigerianinfopedia.com.ng/list-accredited-universities-nigeria-offer-distance-learning/

Karimova, T. \& Garibli, E. (2019). Lifelong economic education based on distance learning education. $5^{\text {th }}$ International Conference on Lifelong Education and Leadership for ALL-ICLEL 2019, (p. 93-98). Sakarya.

Keskin, S. \& Yurdugül, H. (2020). Factors affecting students' preferences for online and blended learning: Motivational vs. cognitive. European Journal of Open, Distance and E-Learning, 22 (2), 72-86.

Lawal, I. (2020, 4 2). Why Nigeria Must Invest in Open, Distance Learning by Prof Jegede. Retrieved 4 23, 2020, from The Guardian Newspapers: guardian.ng/features/why-nigeria-must-invest-in-open-distance-learning-by-prof-jegede/

Law of Georgia on Higher Education (2004). Retrieved April 4, 2020 from https://www.eqe.ge//res/docs/2014120816022280962.pdf

Law of Georgia on General Education. (2005). Retrieved April 4, 2020 from https://matsne.gov.ge/en/document/download/29248/56/en/pdf

Law of the Azerbaijan Republic No. 833-IIIQ. About Education (2009). Retrieved April 20, 2020 from https://cislegislation.com/document.fwx?rgn=29005

Learning Portal. (2020). Spotlight: Quality education for all during COVID-19 crisis. Retrieved April 14, 2020 from https://learningportal.iiep.unesco.org/fr/node/73778 
Markle, R.S. (2016). Exploring teacher readiness: What features of professional development enhance motivation to implement technology innovations? PhD dissertation. Retrieved April 9, 2020 from https://scholarcommons.sc.edu/cgi/viewcontent.cgi?article=4905\&context=etd

Ministry of Education, Science, Culture and Sport of Georgia (2020, March 24). Ministry of Education, Science, Culture and Sport of Georgia launches an educational project "Teleskola" in collaboration with First Channel. Retrieved April 15, 2020 from https://www.mes.gov.ge/content.php?id=10248\&lang=eng

Ministry of Education, Science, Culture and Sport of Georgia. (2020, March 23). Measures to prevent the spread of coronavirus in the fields of education, science, culture and sports. Retrieved April 4, 2020 from https://mes.gov.ge/content.php?id=10245\&lang=eng

Ministry of Education, Science, Culture and Sport of Georgia. (2020, March 10). Disinfection works at public and private schools continue. Retrieved April 4, 2020 from https://mes.gov.ge/content.php?id=10217\&lang=eng

Ministry of Education, Science, Culture and Sport of Georgia. (2020, March 1). Innovative teaching methods and digital resources introduced in Georgian schools. Retrieved April 4, 2020 from https://www.unicef.org/georgia/press-releases/innovativeteaching-methods-and-digital-resources-introduced-georgian-schools

Ministry of Education of Azerbaijan. (2020, March 31). The Ministry of Education presents the "Virtual School" project. Retrieved 25 April, 2020 from https://edu.gov.az/en/page/9/18178

Ministry of Education of Azerbaijan. (2020, April 1). "Microsoft Teams" platformasından ödənişsiz istifadə imkanı. Retrieved 25 April, 2020 from https://edu.gov.az/az/page/9/18166

Ministry of Education of Azerbaijan. (2020, March 11). TV lessons are started. Retrieved 25 April, 2020, from https://edu.gov.az/en/page/9/18194

Naidu, S. (2019). The changing narratives of open, flexible and online learning. Distance Education, 40:2, 149-152, DOI: 10.1080/01587919.2019.1612981

National Open University of Nigeria (NOUN). (n.d). Suspension of Academic Activities. Retrieved April 23, 2020, from National Open University of Nigeria (NOUN): https://nou.edu.ng/announcements/suspension-academic-activities

National Universities Commission. (n.d). The list of approved Distance Learning Centers. Retrieved April 23, 2020 from National Universities Commission: https://www.nuc.edu.ng/distance-learning-centers/

Ngampornchai, A. \& Adams, J. (2016). Students' acceptance and readiness for E-learning in Northeastern Thailand. International Journal of Educational Technology in Higher Education, 13, article 34. Retrieved April 20, 2020 from https://educationaltechnologyjournal.springeropen.com/articles/10.1186/s41239-016-0034-x

Obilade, T. (2012, 2 17). Instructional Technology and Distance Education in Nigeria; Historical Background and a Critical Appraisal. Retrieved 23, 2020, from Virginia Tech: https://vtechworks.lib.vt.edu/bitstream/handle/10919/51637/ObiladePosterInstructionalTechnologyEERA.pdf?sequence $=1 \&$ isAllowed $=\mathrm{y}$

Open Univerity UK. (n.d). What is Distance Learning. Retrieved April 10, 2020 from The Open Univerity UK: http://www.open.ac.uk/courses/what-is-distance-learning 
Othman, M. \& Kareem, M. (2014). The study of availability of electronic teaching skills among teachers in the foundation of technical institute (Kirkuk-Technical Institute) with a suggested program prepared for that purpose. Tanmiyat Al-Rafidain, 36 (116), 153-178.

Pearson. (n.d). Teaching and Learning Online During a Pandemic. Retrieved April 18, 2020, from Pearson: https://www.pearson.com/uk/educators/higher-education-educators/training-and-support/training-support-digitalproducts/supporting-academic-continuity-during-covid-19.html?cq_ck=1584373477444

Peterson's (n.d.). The History of Online Education. Retrieved April 24, 2020 from https://www.petersons.com/blog/the-history-ofonline-education/

Prokofiev, M., Chilikin, M. \& Tulpanov, S. (1961). Higher Education in the USSR. Paris: UNESCO

Rafferty, A.E., Jimmieson, N.L., \& Armenakis, A.A. (2013). Change readiness: A multilevel review. Journal of Management, 39 (1), 110-135. DOI: $10.1177 / 0149206312457417$

Raimers, F.M. \& Schleicher, A. (2020). A Framework to Guide an Education Response to the COVID-19 Pandemic of 2020. OECD. Retrieved April 14, 2020 from https://globaled.gse.harvard.edu/files/geii/files/framework_guide_v2.pdf

Republic of Azerbaijan Cabinet of Ministers. (2020, March 2). Təhsil müəssisələrində tədris, təlim-tərbiyə prosesi mart ayının 3dən dayandırıldı [Starting from March 3 education-related activities were suspended]. Retrieved 25 April 2020 from ttps://cabmin.gov.az/az/article/691/

Rinker, T. (2014). The Treatment of Likert Data. Retrieved January 13, 2020 from https://www.researchgate.net/publication/262011454_Likert

Sadeghi, M. (2019). A shift from classroom to distance learning: advantages and limitations. International Journal of Research in English Education, 4 (1), 80-88.

Santana de Oliveira, M.M. \& Torres Penedo, A.S. \& Pereira, V. (2018). Distance education: Advantages and disadvantages of the point of view of education and society. Dialogia, 29, 139-152.

Sulakauri. (2020, March 13). Uphaso el-sakhelmdzghvaneloebi da damkhmare resursebi (In Georgian: Free e-textbooks and additional resources). Retrieved April 6, 2020 from https://sulakauri.edu.ge/uphaso-el-sakhelmdzghvaneloebi-dadamkhmare-resursebi/

The Guardian (2020, March 26). How to study at home during coronavirus - by online students and tutors. Retrieved April 19, 2020 from https://www.theguardian.com/education/2020/mar/26/how-to-study-at-home-during-coronavirus-byonline-students-and-tutors

The Guardian. (2020, March 12). UK universities switching to online lectures and exams. Retrieved April 19, 2020 from https://www.theguardian.com/world/2020/mar/12/uk-universities-switching-to-online-lectures-and-exams

The Ministry of Education and Science of Ukraine (2020, February 02). The Ministry of Education and Science of Ukraine Recommends Organizing Distance Learning for Students from People's Republic of China Who Are Not Currently in Ukraine. Retrieved April 10, 2020 from https://mon.gov.ua/eng/news/ministry-education-and-science-ukrainerecommends-organizing-distance-learning-students-peoples-republic-china-who-are-not-currently-ukraine

Trapitsin, S., Granichin, O., Granichina, O., \& Zharova, M. (2018). Innovative behavior of teachers: Definition and analysis. $18^{\text {th }}$ conference Professional Culture of the Specialist of the Future. The European Proceedings of Social \& Behavioural 


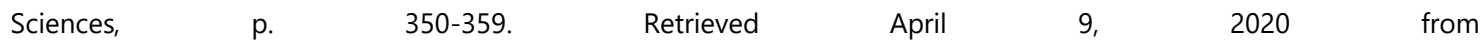

https://www.futureacademy.org.uk/files/images/upload/18thPCSF2018F037.pdf

Weller, M. (2020, 12.03). The COVID-19 Online Pivot: Adapting University Teaching to Social Distancing. Retrieved April 10, 2020 from LSE Impact Blog: https://blogs.lse.ac.uk/impactofsocialsciences/2020/03/12/the-covid-19-online-pivot-adaptinguniversity-teaching-to-social-distancing/

UNIAN information Agency. (2020, March 30). Ukraine launching "National Online School" project. Retrieved April 10, 2020 from https://www.unian.info/society/10936646-ukraine-launching-national-online-school-project.html

UNICEF Azerbaijan. (8 April 2020). UNICEF Azerbaijan launches \#LearningAtHome Challenge. Retrieved 25 April, 2020 from https://www.unicef.org/azerbaijan/press-releases/unicef-azerbaijan-launches-learningathome-challenge

Wishard, J. \& Thomas, M. (2015). Introducing e-research in educational contexts, digital methods and issues arising. Introducing e-research in educational contexts, digital methods and issues arising. International Journal of Research \& Method in Education, 38 (3), 223-229. DOI: 10.1080/1743727X.2015.1036852

youtube (2020). Universitetebi da COVID-19 pandemia (In Georgian: Universities and COVID-19 pandemic). Retrieved April 10, 2020 from

https://www.youtube.com/watch?reload=9\&v=78FyxGZ_5NQ\&feature=youtu.be\&fbclid=IwAROLZw0rf8VkJhmf7FiJ_KYh jC_VsKk-RoVAcyfBiY1wEoVEKscTIZpRqBI

Zimmerman, A., Bos, N., Olson, J. \& Olson, G. (2009). The promise of data in e-research: Many challenges, multiple solutions, diverse outcomes. In Jankovski, N. E-Research: Transformations in Scholarly Practice, p. 222-239. New York: Routledge. 


\section{Appendix: questionnaire}

Dear colleagues,

The goal of this research is by no means to criticize any educational institution or system of education (country), it is just to find out how prepared we happened to be for the need of prolonged total digital education and whether teachers really are at least digital immigrants and students - digital citizens. I believe that the obtained results should be first of all useful for educational policy makers.

The research is anonymous confidential and thus will in no way harm any respondent.

The expected participants are: school and university teachers.

Please answer a few demographic data questions:

Country you live (work) in -

Are you a) school teacher

b) university teacher

What is your age? a) below 30
b) $31-50$
c) above 50

Please send your responses to my e-mail or messenger. I wanted to use some digital online questionnaire, but I couldn't find out how the responses from different countries as well as from schools / universities could be filtered. I realize it will be huge work if many people react, but I hope I will be able to cope with it. I want to publish results in a month, so, volunteer respondents, please hurry.

I welcome co-authorship of this research from different countries (please write to me). I want to publish results in a month, so, volunteer co-authors (who will help with data collection) please hurry.

Prof., Dr. Natela Doghonadze

Please assess out of 6 points how much you agree with the statements below (1- completely disagree, 2- disagree, 3 - do not have a certain opinion / have much doubt, 4 - more or less agree , 5 - agree, 6 - completely agree.

1) * Not all teachers in my institution have high enough quality internet on some digital device (PC, laptop, mobile phone, etc.) which enables distance teaching

$$
\begin{array}{llllll}
1 & 2 & 3 & 4 & 5 & 6
\end{array}
$$

2) All teachers in my institution possess technical skills to carry out distance teaching without somebody's help / additional training.

$\begin{array}{llllll}1 & 2 & 3 & 4 & 5 & 6\end{array}$

3) The majority of teachers were sincerely enthusiastic about the introduction of compulsory distance teaching for an indefinite (probably quite long) time. 


$\begin{array}{llllll}1 & 2 & 3 & 4 & 5 & 6\end{array}$

4) * For me personally the introduction of compulsory distance teaching for an indefinite (probably quite long) time was quite stressful.

$\begin{array}{llllll}1 & 2 & 3 & 4 & 5 & 6\end{array}$

5) * Not all students in my institution have high enough quality internet on some digital device (PC, laptop, mobile phone, etc.) which enables distance learning.

$\begin{array}{llllll}1 & 2 & 3 & 4 & 5 & 6\end{array}$

6) All students in my institution possess technical skills to carry out distance teaching without somebody's help / additional training.

$\begin{array}{llllll}1 & 2 & 3 & 4 & 5 & 6\end{array}$

7) The majority of students were sincerely enthusiastic about the introduction of compulsory distance learning for an indefinite (probably quite long) time.

$\begin{array}{llllll}1 & 2 & 3 & 4 & 5 & 6\end{array}$

8) The introduction of distance education in my country was quite successful

$\begin{array}{llllll}1 & 2 & 3 & 4 & 5 & 6\end{array}$

